\title{
Hydrosilylation in Aryliminopyrrolide-Substituted Silanes
}

\author{
Léon Witteman, ${ }^{[a]}$ Tim Evers, $^{[a]}$ Zhan Shu, ${ }^{[a]}$ Martin Lutz, ${ }^{[b]}$ Robertus J. M. Klein Gebbink, ${ }^{[a]}$ and \\ Marc-Etienne Moret ${ }^{*[a]}$
}

\begin{abstract}
A range of silanes was synthesized by the reaction of $\mathrm{HSiCl}_{3}$ with iminopyrrole derivatives in the presence of $\mathrm{NEt}_{3}$. In certain cases, intramolecular hydrosilylation converts the imine ligand into an amino substituent. This reaction is inhibited by factors such as electron-donating substitution on $\mathrm{Si}$ and steric bulk. The monosubstituted ( $\left.{ }^{\text {Dipp }} \mathrm{IMP}\right) \mathrm{SiHMeCl}$

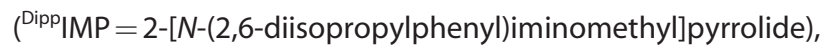
is stable towards hydrosilylation, but slow hydrosilylation is observed for ( ${ }^{\text {Dipp } I M P)} \mathrm{SiHCl}_{2}$. Reaction of two equivalents of
\end{abstract}

\begin{abstract}
${ }^{\text {Dipp }} \mathrm{IMPH}$ with $\mathrm{HSiCl}_{3}$ results in the hydrosilylation product

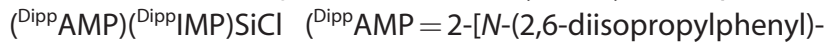
aminomethylene]pyrrolide), but the trisubsitituted ( ${ }^{\text {Dipp }}$ IMP) ${ }_{3} \mathrm{SiH}$ is stable. Monitoring the hydrosilylation reaction of ( ${ }^{\text {Dipp }}$ IMP) $\mathrm{SiHCl}_{2}$ reveals a reactive pathway involving ligand redistribution reactions to form the disubstituted ( $\left.{ }^{\text {Dipp }} \mathrm{AMP}\right)\left({ }^{\text {Dipp }} \mathrm{IMP}\right) \mathrm{SiCl}$ as an intermediate. The reaction is strongly accelerated in the presence of chloride anions.
\end{abstract}

\section{Introduction}

Silicon(II) compounds supported by nitrogen ligands are attracting renewed interest because of their use as strongly donating, high-field ligands. ${ }^{[1-3]}$ The first stable silylene was developed by using a chelating dianionic N-donor substituent that forms a five-membered ring with silicon(II), ${ }^{[4]}$ in an analogous fashion to Arduengo's N-heterocyclic carbene. ${ }^{[5]}$ In recent years, stable silylenes have also been isolated with a range of monoanionic, bidentate $\mathrm{N}$-donor substituents such as (bis)amidinato, (bis)guanidinato, ${ }^{[6-12]}$ and $\beta$-diketiminates. ${ }^{[13-16]}$ Furthermore, a free silicon(II) anion has recently been afforded by cleavage of one pyrazolyl from a tetrapyrazolyl silane, ${ }^{[17]}$ which has been coordinated to transition metals such as $\mathrm{Pd}, \mathrm{Pt}$, and $\mathrm{Cu}^{[18,19]}$ demonstrating the use of electron-withdrawing heterocyclic substituents to stabilize novel low-valent silicon chemistry.

In this context, the coordination chemistry of pyrrolyl-substituted silicon(II) ligands is underdeveloped. In one isolated example, tris- $N$-pyrrolylsilane has been shown by Hübler, Roper, and Wright ${ }^{[1]}$ to undergo $\mathrm{Si}-\mathrm{H}$ oxidative addition to $\mathrm{Ru}$ and $\mathrm{Os}$ complexes to form the tris- $N$-pyrrolylsilyl ligand, which is strongly $\pi$-accepting because of the electron-withdrawing

[a] L. Witteman, T. Evers, Z. Shu, Prof. Dr. R. J. M. Klein Gebbink, Dr. M.-E. Moret Department of Chemistry

Debye Institute for Nanomaterials Science Utrecht University

Universiteitsweg 99, 3584 CG Utrecht (The Netherlands)

E-mail:m.moret@uu.nl

[b] Dr. M. Lutz

Crystal and Structural Chemistry, Bijvoet Center for Biomolecular Research Faculty of Science, Utrecht University Padualaan 8, 3584 CH Utrecht (The Netherlands)

$\square$ Supporting information and the ORCID identification number for the

(iD author of this article can be found under http://dx.doi.org/10.1002/ chem.201505033. character of the pyrrolyl substituents. Nevertheless, a range of pyrrolyl-substituted silanes is known. The better part of the existing compounds with an $\mathrm{N}$-pyrrolylsilyl substructure is being studied in the form of 1) phthalocyanines, ${ }^{[20]}$ porphyrins, ${ }^{[21]}$ and analogues thereof; 2) silyl-protected pyrroles ${ }^{[22]}$ (mainly $\mathrm{R}_{3} \mathrm{SiPyr}$ where $\mathrm{R}=$ alkyl or aryl); or 3) chemical vapor deposition (CVD) precursors $\left(\mathrm{Pyr}_{n} \mathrm{SiH}_{(4-n)} ; n=1-3\right){ }^{[23]}$ Furthermore, three research groups have specifically studied the structure and reactivity of pyrrolylsilane derivatives (Scheme 1): the dihydroxyphenol dipyrrin (I) by Sakamoto et al., ${ }^{[24]}$ the (NNO) pyrrolehydroxyphenol carbaldimine (II) by Gerlach et al., ${ }^{[25,26]}$ and dipyrrins (III) and acylpyrroles (IV) by Kämpfe et al. ${ }^{[27-29]}$ Interestingly, the latter comment that the acyl moiety in IV does not undergo hydrosilylation; the acylpyrrolide hydrosilanes involved during the preparation of IV preferentially liberate $\mathrm{H}_{2}$ upon reaction with the second ligand.
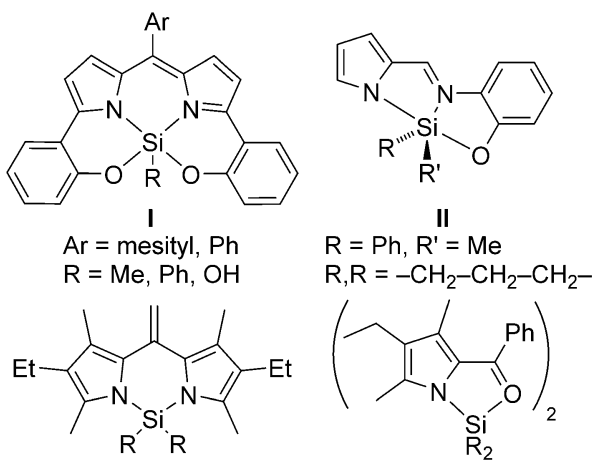

III

$\mathrm{R}=\mathrm{Ph}, \mathrm{Me}$

$\mathrm{R}, \mathrm{R}=-\mathrm{CH}_{2}-\mathrm{CH}_{2}-\mathrm{CH}_{2}-$

IV

$\mathrm{R}=\mathrm{Cl}, \mathrm{OTf}, \mathrm{F}, \mathrm{Ph}$

Scheme 1. Previously reported pyrrolyl silanes. ${ }^{[24-29]}$ 
Aryliminopyrrolide ligands (related to II, albeit with a noncoordinating aryl function) have found broad usage as bidentate and monoanionic ligands for transition metals and f-block elements. ${ }^{[30]}$ However, the use of these ligands in main-group chemistry is less developed. The most widely studied maingroup aryliminopyrrolide complexes are based on aluminum. ${ }^{[31-35]}$ In particular, these Al-complexes find usage as catalysts in lactide ring-opening polymerization (ROP) ${ }^{[36-38]}$ and guanylation. ${ }^{[39]}$ Anderson et al. have prepared a range of aryliminopyrrolide phosphines as $\mathrm{P}, \mathrm{N}$-chelating ligands on $\mathrm{Rh}, \mathrm{Pd}$, and $\mathrm{Ni}$ complexes for olefin oligomerization, ${ }^{[40 a]}$ and Vránová et al. synthesized aryliminopyrrolyl antimony chloride. ${ }^{[40 b]}$ Furthermore, 2-[N-(2,6-diisopropylphenyl)iminomethyl]-5-tert-butylpyrrolide has recently been shown to afford a series of stable Ge"l compounds by Yang et al. ${ }^{[35]}$

Aiming at the development of new silicon(II) ligands for transition-metal chemistry, we set out to study the silicon chemistry of the aryliminopyrrolide ligand 2-[N-(2,6-diisopropylphenyl)iminomethyl]pyrrolide (DippIMP; Scheme 2). We

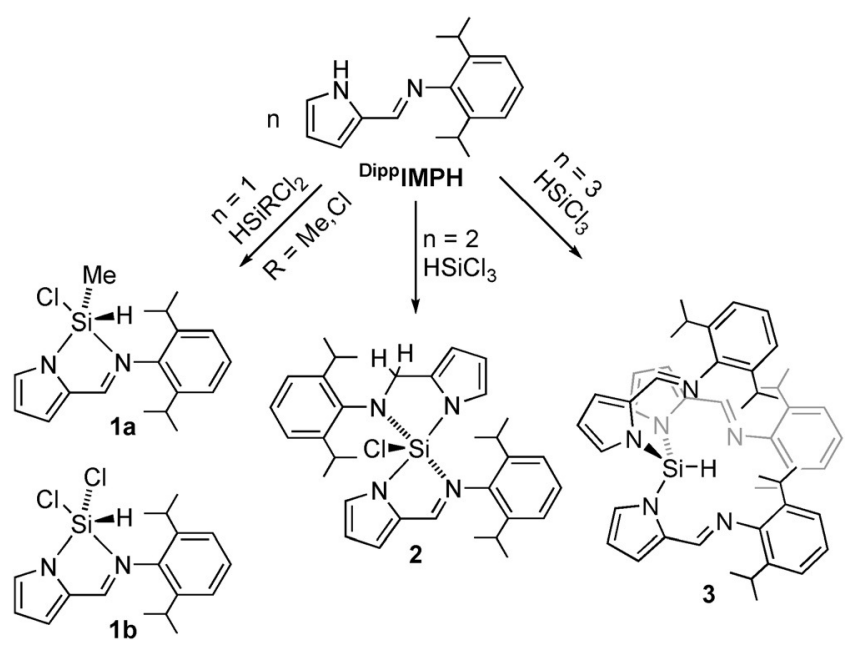

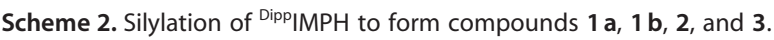

report herein the reactions of DippIMPH with hydrosilanes. In some cases, the tethered imine functionality in the Dipp IMP ligand is found to undergo intramolecular 1,2-hydrosilylation. In related iminohydrosilanes a hydrosilylation reaction of the tethered imine functionality was also observed. ${ }^{[41-43]}$ Furthermore, 1,4-hydrosilylation has been observed in a phenanthroline hydrosilane by Fester et al. ${ }^{[44]}$ To contribute to a better understanding and control of this generally undesired reaction, we investigated the factors controlling the hydrosilylation process. In particular, this reaction was found to be catalyzed by the chloride anion and can be sterically inhibited.

\section{Results and Discussion}

\section{Synthesis of monosubstituted aryliminopyrrolide silanes}

The iminopyrrole Dipp IMPH was conveniently obtained in one step from 2-formylpyrrole and 2,6-diisopropylaniline according to the procedure of $\mathrm{Li}$ et al. ${ }^{[45]}$ In a first experiment, analogous to the reported procedure for tris- $N$-pyrrolylsilane, ${ }^{[1]}$ Dipp IMPH was treated with dichloromethylsilane (1 equiv) at $-78^{\circ} \mathrm{C}$ in the presence of triethylamine $\left(\mathrm{NEt}_{3}\right)$ to give monosubstituted compound 1 a (Scheme 2). A single ${ }^{29} \mathrm{Si}$ NMR signal at $-64.9 \mathrm{ppm}$ indicates a pentacoordinate geometry around silicon resulting from coordination of the imine moiety. The $\mathrm{Si}-\mathrm{H}$ bond in $1 \mathrm{a}$ is intact, as evidenced by a ${ }^{1} \mathrm{H}$ NMR signal at $6.16 \mathrm{ppm}$ with ${ }^{29} \mathrm{Si}$ satellites $\left({ }^{1} \mathrm{~J}(\mathrm{Si}, \mathrm{H})=312 \mathrm{~Hz}\right)$, the doublet of quartets splitting pattern of the ${ }^{29} \mathrm{Si}$ resonance $\left({ }^{1} J(\mathrm{Si}, \mathrm{H})=\right.$ $\left.312 \mathrm{~Hz},{ }^{2} J(\mathrm{Si}, \mathrm{H})=8.5 \mathrm{~Hz}\right)$, and an IR absorption at $2211 \mathrm{~cm}^{-1}$. Furthermore, the $\mathrm{H}-\mathrm{H}$ COSY spectrum of 1 a displays a diagnostic cross peak between the $\mathrm{Si}-\mathrm{H}(6.16 \mathrm{ppm})$ and $\mathrm{Si}-\mathrm{CH}_{3}$ (0.64 ppm) resonances with a coupling constant of approximately $1.7 \mathrm{~Hz}$, confirming the existence of the H-Si-Me fragment. The ${ }^{1} \mathrm{H}$ NMR signals corresponding to the isopropyl groups of $1 \mathrm{a}$ appear broad at room temperature, which may be indicative of a fluxional process. Indeed, VT NMR measurements (Supporting Information, Figure S5) show that the two isopropyl groups are inequivalent at low temperature $\left(-20^{\circ} \mathrm{C}\right)$ but rapidly exchange at high temperature $\left(>60^{\circ} \mathrm{C}\right)$, with a coalescence temperature of $28^{\circ} \mathrm{C}$, corresponding to a free enthalpy of activation of $\Delta G^{+}{ }_{301 \mathrm{~K}}=14.1 \mathrm{kcal} \mathrm{mol}^{-1} \cdot{ }^{[46]}$ This fluxional process is assigned to the hindered rotation around the single $\mathrm{C}_{\text {ary }}-\mathrm{N}_{\text {imine }}$ bond, presumably through reversible dissociation of the $\mathrm{N}_{\text {imine }} \rightarrow \mathrm{Si}$ coordination bond. This interpretation is additionally supported by a relaxed potential energy surface (PES) scan of this rotation (Supporting Information, Figure S50) calculated at the B3LYP/6-31G $(d, p)$ level of theory, from which an activation energy ( $\left.\Delta E_{\text {electronic }}\right)$ of $12.8 \mathrm{kcal} \mathrm{mol}^{-1}$ can be estimated, in good agreement with the experimental $\Delta G^{\neq}$value of $14.1 \mathrm{kcal} \mathrm{mol}^{-1}$. The PES scan shows an increase in distance between the silicon and imine nitrogen from $2.33 \AA$ in the stable configuration to a maximum of $3.15 \AA$ for the highest energy configuration (Supporting Information, Figure S51). Given the extended conformational space associated with the "crossing" of two flexible, bulky substituents, optimization of a single transition state was not attempted for this process.

The pentacoordinate structure inferred from the ${ }^{29} \mathrm{Si} N M R$ chemical shift was confirmed by an X-ray crystal structure determination (Figure 1). The structure exhibits a distorted trigonal bipyramidal (TBP) geometry $(\tau=0.83)^{[47]}$ with the imine nitrogen atom and the chloride substituent in apical positions. This geometry can be rationalized by the fact that the apical positions in a hypervalent TBP geometry are usually occupied by the most electron-withdrawing substituents (apicophilic) that engage in a three-center-four-electron $(3 \mathrm{c}-4 \mathrm{e})$ bond with a pair of electrons delocalized over the substituents. ${ }^{[48]}$

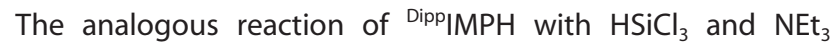
gave a more complex mixture of products (see below) that contained the monosubstituted compound $\mathbf{1} \mathbf{b}$ as a major component (Scheme 2), but from which we were unable to isolate it. This problem was circumvented by using a different synthesis: the iminopyrrole was first deprotonated with $n \mathrm{BuLi}$, and the obtained salt ${ }^{D i p p} I M P L i$ was treated with $\mathrm{HSiCl}_{3}$ at $-78^{\circ} \mathrm{C}$ to yield analytically pure $1 \mathrm{~b}$ after recrystallization from hexanes. The intact $\mathrm{Si}-\mathbf{H}$ bond in $\mathbf{1} \mathbf{b}$ is evidenced by the corre- 


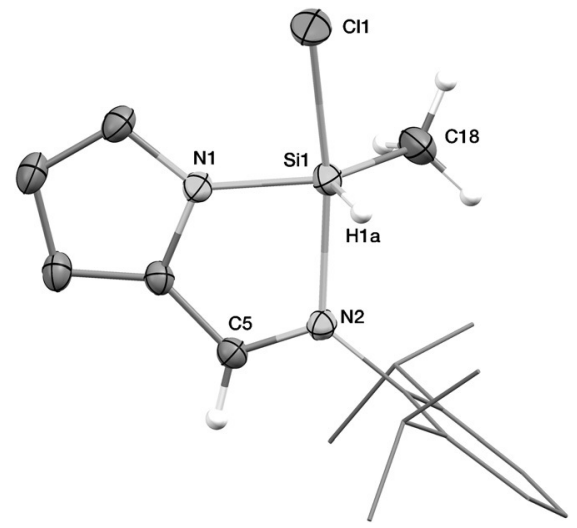

Figure 1. Molecular structure $\mathbf{1} \mathrm{a}$ in the crystal. Ellipsoids are set at $50 \%$ probability, hydrogen atoms other than $\mathrm{CH}_{3}, \mathrm{SiH}$, and $\mathrm{N}=\mathrm{CH}$ are omitted and the aryl group is displayed as wireframe for clarity. Selected bond distances $[\AA]$ and angles $\left[{ }^{\circ}\right]$ : Si1-N1 1.7884(9), Si1-N2 2.0663(9), Si1-C18 1.8568(14), Si1-Cl1 2.2330(4); N1-Si1-N2 81.10(4), N1-Si1-C18 120.89(6), N1-Si1-Cl1 92.02(3), N2-Si1-Cl1 170.67(3)

sponding IR absorption $\left(2208 \mathrm{~cm}^{-1}\right)$, a doublet signal for $\mathrm{Si}-\mathrm{H}$ in ${ }^{1} \mathrm{H}$ NMR $\left(6.57 \mathrm{ppm},{ }^{4} \mathrm{~J}(\mathrm{H}, \mathrm{H})=1.8 \mathrm{~Hz}\right)$ flanked by ${ }^{29} \mathrm{Si}$ satellites, and a doublet ${ }^{29} \mathrm{Si}$ NMR signal $\left(-92.7 \mathrm{ppm},{ }^{1} \mathrm{~J}(\mathrm{Si}, \mathrm{H})=385 \mathrm{~Hz}\right)$. The doublet signal in the ${ }^{1} \mathrm{H}$ NMR spectrum arises from a ${ }^{4} \mathrm{~J}$ coupling between $\mathrm{Si}-\mathrm{H}$ and $\mathrm{N}=\mathrm{C}-\mathrm{H}$, as confirmed by $\mathrm{H}-\mathrm{H}$ COSY. The ${ }^{29} \mathrm{Si} \mathrm{NMR}$ chemical shift is consistent with a five-coordinate geometry analogous to that of $1 \mathrm{a}$, which is to be expected because of the stronger Lewis acidity expected after formal replacement of a methyl group in 1 a by a more electron-withdrawing chloro-substituent in $\mathbf{1} \mathbf{b}$.

\section{Fluxional processes in $\mathbf{1 ~ b}$}

In contrast to what is observed for $\mathbf{1} \mathrm{a}$, the two isopropyl groups in $\mathbf{1} \mathbf{b}$ are equivalent on the ${ }^{1} \mathrm{H}$ NMR timescale at room temperature and down to $-80^{\circ} \mathrm{C}$, as evidenced by a single septet at $2.83 \mathrm{ppm}$ (Figure 2). The methyl groups appear as two doublets that coalesce at $60^{\circ} \mathrm{C}$, corresponding to a free enthalpy of activation of $\Delta G^{+} 333 \mathrm{~K}=15.6 \mathrm{kcal} \mathrm{mol}^{-1}$ at this tem-

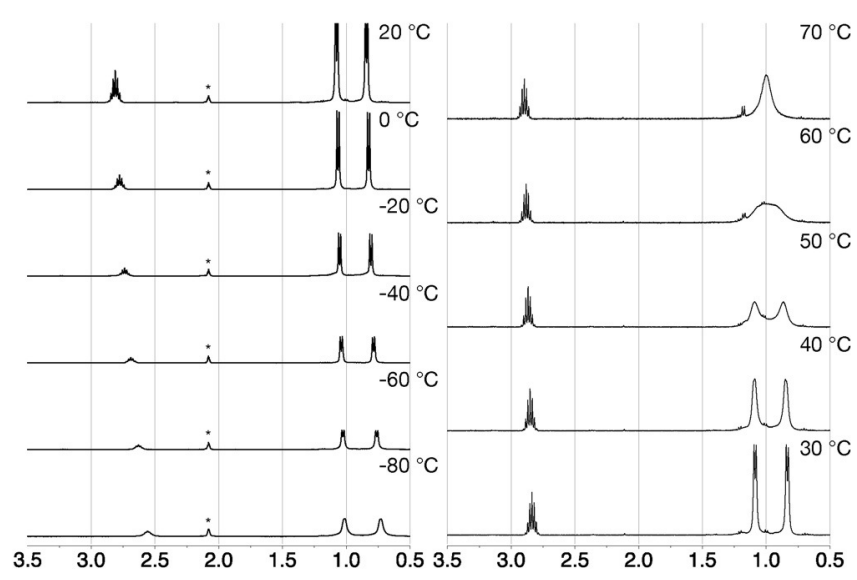

Figure 2. LT-NMR $\left(-80^{\circ} \mathrm{C}<T<20^{\circ} \mathrm{C}\right.$ ) of $1 \mathrm{~b}$ in $\mathrm{C}_{7} \mathrm{D}_{8}$ (left) and HT-NMR $\left(30^{\circ} \mathrm{C}\right.$ $<T<70^{\circ} \mathrm{C}$ ) in $\mathrm{C}_{6} \mathrm{D}_{6}$ (right). * denotes $\mathrm{C}_{7} \mathrm{D}_{8}$ residual signal. perature. That process is assigned to rotation around the $\mathrm{C}_{\text {aryl }}-$ $\mathrm{N}_{\text {imine }}$ bond, similar to $1 \mathrm{a}$, because this has an activation barrier of $\Delta G^{+}{ }_{301 \mathrm{~K}}=14.1 \mathrm{kcal} \mathrm{mol}^{-1}$ for $1 \mathrm{a}$ and would be expected to have a similar activation barrier for $\mathbf{1} \mathbf{b}$ on the basis of steric hindrance. At first sight, the two equivalent isopropyl groups (a single resonance for both $\mathrm{C}-\mathrm{H}$ ) might be seen as suggesting a $C_{s}$ symmetrical geometry in which the $\mathrm{Si}-\mathrm{H}$ bond would occupy an apical position, which however should be unfavorable on electronic grounds. An alternative explanation would be that the ground-state geometry is unsymmetrical (in analogy with that of $\mathbf{1} \mathrm{a}$ ) and that the two isopropyl groups are exchanged by a rapid fluxional process. Having identified that the rotation around the $\mathrm{C}_{\text {aryl }}-\mathrm{N}_{\text {imine }}$ bond occurs only above $60^{\circ} \mathrm{C}$ on the NMR timescale, a different process must be in play. This process can be envisioned to be a facile Berry pseudorotation-type mechanism ${ }^{[49]}$ around the five-coordinate silicon atom. Reported activation energies for conformer interconversion in both pentacoordinate silanes and silicates vary from 8 to $15 \mathrm{kcal} \mathrm{mol}^{-1} \cdot{ }^{[50-53]}$ In structurally similar dibromo phenyl $\kappa^{2}-2-[($ dimethylamino)methyl] phenyl tin studied by van Koten et al., a low energy barrier for conformer interconversion has also been observed (coalescence temperature ca. $\left.-90^{\circ} \mathrm{C}\right){ }^{[54]}$ Comparable with our observations, the energy barrier is significantly higher in the bromo methyl phenyl analogue (coalescence temperature $>123^{\circ} \mathrm{C}$ )..$^{[5]}$

More light on fluxional processes in $\mathbf{1} \mathbf{b}$ was shed by DFT calculations (Figure 3). The lowest-energy structure was found to be the TBP structure $\mathbf{I}^{1}$ with the imine nitrogen atom and a chlorine substituent in the axial positions, analogous to the crystal structure of $1 \mathrm{a}$. We identified two low-energy pathways that would exchange the two isopropyl groups; that is, swap the two faces of the iminopyrrole plane and epimerize the Si center. The first pathway proceeds through a single transition state $\left(\mathrm{TS}^{1}\right)$ in which rotation around the $\mathrm{N}_{\text {pyrrole }}-\mathrm{Si}$ bond is coupled to decoordination of the imine moiety $\left(\mathrm{Si}-\mathrm{N}_{\text {imine }}\right.$ : $3.23 \AA$ ) and which is associated with a free enthalpy of activation of $\Delta G^{+}{ }_{298 \mathrm{~K}}=4.9 \mathrm{kcal} \mathrm{mol}^{-1}$. The second exchange pathway, with an overall barrier of $\Delta G^{+}{ }_{298 \mathrm{~K}}=9.1 \mathrm{kcal} \mathrm{mol}^{-1}$, starts with a Berry pseudorotation $^{[56,57]}$ with the hydrogen atom as the pivot to form the TBP intermediate $I^{2}$, followed by a second Berry-like step bringing the $\mathrm{Si}-\mathrm{H}$ bond in the axial position in the symmetrical intermediate $\mathrm{I}^{3}$, which lies $3.5 \mathrm{kcal} \mathrm{mol}^{-1}$ above the ground-state structure $\mathrm{I}^{1}$. The $\mathrm{Si}-\mathrm{N}_{\text {imine }}$ bond in $\mathrm{I}^{3}$ is considerably elongated $(2.96 \AA)$, which is likely due to the low apicophilicity of hydrogen, leading us to describe this structure as tetrahedral with only a weak $\mathrm{Si}-\mathrm{N}_{\text {imine }}$ interaction.

The predicted existence of multiple low-energy pathways for the epimerization of the Si center is consistent with the observation of a single $\mathrm{C}-\mathrm{H}$ resonance for the isopropyl groups. The two methyl groups on a single isopropyl residue are diastereotopic and are not exchanged by the epimerization of the $\mathrm{Si}$ center only, but by an additional rotation around the $\mathrm{C}_{\text {ary }}-$ $\mathrm{N}_{\text {imine }}$ bond. The activation energy for this process was estimated by a relaxed PES scan (Supporting Information, Figure S50), which yielded an activation energy ( $\left.\Delta E_{\text {electronic }}\right)$ of $15.3 \mathrm{kcal}$ $\mathrm{mol}^{-1}$, in good agreement with the measured free enthalpy of activation $\Delta G^{+}{ }_{333 \mathrm{~K}}=15.6 \mathrm{kcal} \mathrm{mol}^{-1}$ for the exchange of the 


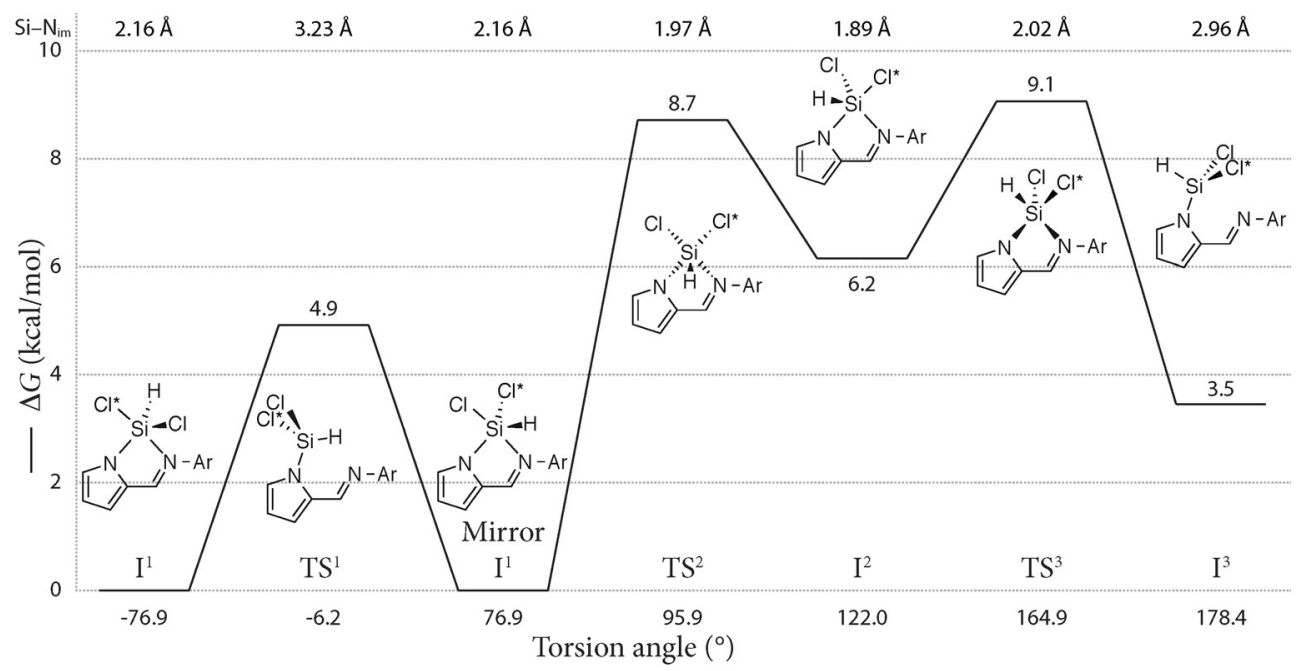

Figure 3. Calculated mechanism of epimerization at silicon in $\mathbf{1} \mathbf{b}$. For clarity, one of the chlorine atoms is marked with an $\star$. Method used: B3LYP/6-31G(d,p). Torsion angle pyrC2-N-Si-H is given on the horizontal axis, the $\mathrm{Si}-\mathrm{N}_{\mathrm{im}}$ distance is given on top, $\Delta G$ calculated at $298.15 \mathrm{~K}$.

methyl groups. As noted for $1 \mathrm{a}$, because of the extended conformational space associated with the "crossing" of two flexible, bulky substituents, the optimization of a single transition state was not attempted for this process.

The two Si-epimerization pathways in $1 \mathrm{~b}$ can be loosely described as an overall $360^{\circ}$ rotation around the $\mathrm{N}_{\text {pyrrole }}-\mathrm{Si}$ bond with decoordination of the $\mathrm{N}_{\text {imine }}$ in the symmetrical intermediate $\mathbf{I}^{3}$ and transition state TS $^{1}$ (Figure 3 ). Hence, they would not epimerize a Si center with five different substituents, as the chiral information would not be lost in the tetrahedral structures $\mathbf{T S}^{1}$ and $\mathbf{I}^{3}$. This explains why two distinct isopropyl moieties are observed in the ${ }^{1} \mathrm{H}$ NMR spectrum of the Me-substituted analogue $1 \mathrm{a}$ up to the temperature at which $\mathrm{C}_{\text {aryl }}$ $\mathrm{N}_{\text {imine }}$ bond rotation becomes fast on the ${ }^{1} \mathrm{H}$ NMR timescale.

Compounds $1 \mathrm{a}$ and $\mathbf{1} \mathbf{b}$ are new members of the family of pentacoordinate silanes with bidentate $\mathrm{N}, \mathrm{N}$-substituents. Only two other compounds in this family bear bidentate monoanionic $\mathrm{N}, \mathrm{N}$-substituents that form a five-membered ring with silicon; namely, the trimethyl- and trichloro aminotroponimine silanes developed by Dias et al. ${ }^{[58]}$ In contrast to these, silanes $\mathbf{1 a}$ and $\mathbf{1} \mathrm{b}$ bear both a hydrogen and chloride substituent, which are known to be easily abstracted with an alkali metal non-coordinating base to yield silylenes in other monoanionic, $\mathrm{N}, \mathrm{N}$-bidentate chloro hydrosilanes, for example, chlorobis(amidinato)hydro silane. ${ }^{[59]}$

\section{Higher degree of substitution}

With the synthesis and characterization of the monosubstituted compounds $\mathbf{1} \mathbf{a}$ and $\mathbf{1} \mathbf{b}$ in hand, we sought to increase the number of iminopyrrolide substituents on silicon. The reaction of two equivalents ${ }^{\mathrm{Dipp}} \mathrm{IMPH}$ with $\mathrm{HSiCl}_{3}$ and $\mathrm{NEt}_{3}$ at $-78^{\circ} \mathrm{C}$ gave compound $\mathbf{2}$, the crude formula of which corresponds to the substitution of two chlorides by iminopyrrolide ligands (Scheme 2). The compound was isolated in analytically pure form by recrystallization from acetonitrile at $-35^{\circ} \mathrm{C}$. The
${ }^{1} \mathrm{H}$ NMR spectrum of $\mathbf{2}$ shows a total of eight separate doublets and four septets for the isopropyl $\mathrm{CH}_{3}$ and $\mathrm{CH}$ protons, respectively, indicating disubstitution, bidentate coordination of both substituents, and a low-symmetry structure. Surprisingly, no signal corresponding to a silicon-bound $\mathrm{H}$-atom was found, and the $\mathrm{H}$-coupled ${ }^{29} \mathrm{Si} \mathrm{NMR}$ spectrum displays a singlet at $-116.2 \mathrm{ppm}$, indicating pentacoordination around silicon and the absence of a Si-H moiety. Instead, two mutually coupled doublets appear at $\delta=4.49$ and $4.32 \mathrm{ppm}$, respectively, of which the coupling constant of ${ }^{2} \mathrm{~J}(\mathrm{H}, \mathrm{H})=13.9 \mathrm{~Hz}$ is typical for geminal coupling between diastereotopic methylene protons. Hence, an intramolecular hydrosilylation (1,3-hydride shift) has taken place to form amino-substituted compound $\mathbf{2}$ (Scheme 2). In line with this interpretation, the signal from the remaining imine methine proton $(\delta=7.39 \mathrm{ppm})$ accounts for only one proton. The structure of $\mathbf{2}$ was confirmed by an X-ray crystal structure determination (Figure 4), showing again a distorted TBP structure $(\tau=0.86)^{[47]}$ in which the apical positions are occupied by the pyrrole moieties. This contrasts with the geometry observed for the monosubstituted compounds 1 a and $\mathbf{1} \mathbf{b}$, which can be explained by the steric influence of the dipp moieties, which minimize their repulsion with each other and with the pyrrole groups in this geometry. The electronwithdrawing nature of the pyrrole group ${ }^{[1]}$ likely allows them to engage in a $3 c-4 e$ bond. ${ }^{[25,26,60]}$ In the crystal structure, the molecule is located on an exact crystallographic twofold rotation axis. Consequently, the imine $\mathrm{CH}$ group and the aminomethylene $\mathrm{CH}_{2}$ group resulting from hydrosilylation are equivalent by symmetry. $\mathrm{A}$ disorder model in a 1:1 ratio was used to resolve this issue.

Trisubstitution at silicon was achieved by reacting three equivalents of ${ }^{\text {Dipp }} \mathrm{IMPH}$ with $\mathrm{HSiCl}_{3}$ in the presence of triethylamine to give silane 3 . The presence of a $\mathrm{Si}-\mathrm{H}$ bond is evidenced by an IR absorption at $2355 \mathrm{~cm}^{-1}$ and by a doublet in the ${ }^{29} \mathrm{Si}$ NMR spectrum at $\delta=-60.5 \mathrm{ppm}\left({ }^{1} J(\mathrm{Si}, \mathrm{H})=417 \mathrm{~Hz}\right)$. The position of this chemical shift indicates tetracoordination 


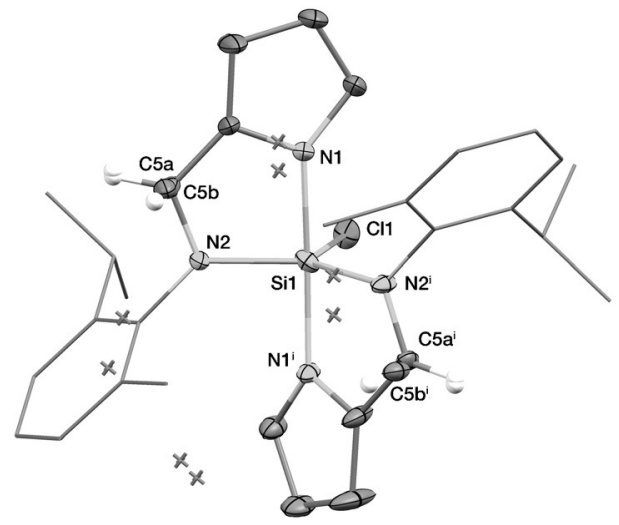

Figure 4. Molecular structure of $\mathbf{2}$ in the crystal. Ellipsoids are set at $50 \%$ probability; hydrogen atoms other than $\mathrm{N}=\mathrm{CH}$ and $\mathrm{N}-\mathrm{CH}_{2}$ are omitted and aryl groups shown as wireframe for clarity. The disordered atoms $\mathrm{C} 5 \mathrm{a} / \mathrm{C} 5 \mathrm{~b}$ were refined with $50 \%$ occupancy, respectively. Symmetry code i: $1-x, y$, $0.5-z$. Selected bond distances $[\AA]$ and angles $\left[{ }^{\circ}\right]$ : Cl1-Si1 2.0994(5), Si1-N1 1.8589(7), Si1-N2 1.7987(7); Cl1-Si1-N1 92.20(3), Cl1-Si1-N2 118.09(3), N1-Si1N2 85.09(3), N1-Si1-N1' 175.60(5), N2-Si1-N2i 123.81(6), N1-Si1-N2 92.83(3).

around silicon; hence, all substituents are bound in a monodentate fashion. In the ${ }^{1} \mathrm{H}$ NMR spectrum, the $\mathrm{Si}-\mathrm{H}$ resonance $(\delta=7.63 \mathrm{ppm})$ has been identified from its ${ }^{29} \mathrm{Si}$ satellites $\left({ }^{1} J(\mathrm{Si}, \mathrm{H})=417 \mathrm{~Hz}\right)$ and integrates to $1 / 3$ with respect to the $\mathrm{N}=$ $\mathrm{CH}$ and pyrrole- $\mathrm{H}$ signals, confirming trisubstitution. Additionally, the limited number of signals indicates that this structure is highly symmetric. For instance, only one signal arising from the $\mathrm{N}=\mathrm{CH}$ is observed, and the combined pyrrole protons give rise to three signals; that is, all substituents are equivalent in solution. This can be explained by a $C_{3}$ rotation axis through the $\mathrm{Si}-\mathrm{H}$ bond. Interestingly, broad signals were observed for the $i \operatorname{Pr} \mathrm{CH}$ and for half of the $i \operatorname{Pr} \mathrm{CH}_{3}$ groups. VT NMR measurements (Supporting Information, Figures S20-S22) show that the two isopropyl groups are inequivalent at low temperature $\left(<-60^{\circ} \mathrm{C}\right)$ but rapidly exchange at high temperature $\left(>80^{\circ} \mathrm{C}\right)$, indicating hindered rotation around the $\mathrm{C}_{\text {ary }}-\mathrm{N}_{\text {imine }}$ bond at moderate temperatures. We tentatively ascribe this hindering to steric effects between the bulky aromatic groups of the different substituents.

This hypothesis is substantiated by the solid-state structure in which the steric congestion between the aryl groups is clearly visible (Figure 5). The structure contains an approximate, noncrystallographic threefold rotation axis through the $\mathrm{Si}-\mathrm{H}$ bond. It is of interest to compare $\mathbf{3}$ and tris- $\mathrm{N}$-pyrrolyl silane $\left(\mathrm{Pyr}_{3} \mathrm{SiH}\right)$, which is the only other structurally characterized pyrrolyl-substituted hydrosilane. The $\mathrm{N}$-Si-N angles in 3 $\left(100.84(5)^{\circ}, 101.47(5)^{\circ}\right.$, and $\left.101.99(5)^{\circ}\right)$ are considerably smaller than those in $\mathrm{Pyr}_{3} \mathrm{SiH}\left(106.8(2)^{\circ}, 107.3(2)^{\circ}\right.$, and $\left.112.8(2)^{\circ}\right)$ and the $\mathrm{N}-\mathrm{Si}$ bonds in 3 are slightly longer $(1.7660(10), 1.7738(11)$, and 1.7760(11) $\AA$ vs. 1.711(4), 1.735(4), and 1.740(4) $\AA$ ), which can be explained by the steric repulsion between the aryl groups being mechanically transmitted through the rigid iminopyrrolide plane. This difference in geometry appears to impact strongly the properties of the $\mathrm{Si}-\mathrm{H}$ bond: the corresponding infrared absorption shifts by approximately $120 \mathrm{~cm}^{-1}$, from $2233 \mathrm{~cm}^{-1}$ in $\mathrm{Pyr}_{3} \mathrm{SiH}$ to $2355 \mathrm{~cm}^{-1}$ in 3, and

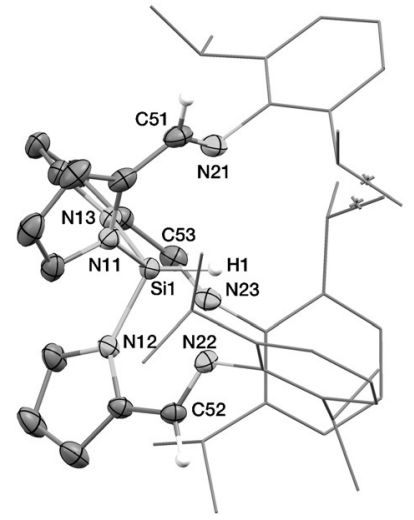

Figure 5. Molecular structure of tetrahedral 3 in the crystal. Ellipsoids are set at $50 \%$ probability; hydrogen atoms other than $\mathrm{SiH}$ are omitted and aryl groups are shown as wireframe for clarity. Selected distances $[\AA]$ and angles ${ }^{\circ}$ ]: N11-Si1 1.7760(11), N12-Si1 1.7660(10), N13-Si1 1.7738(11), N21-Si 2.868(1), N22-Si 2.783(1), N23-Si 2.822(1), N21-C51 1.271(2), N22-C52 1.272(2), N23-C53 1.275(2); N11-Si1-N12 101.47(5), N11-Si1-N13 100.84(5), N12-Si1-N13 101.99(5)

the ${ }^{1} \mathrm{H}$ coupling constant ${ }^{1} J(\mathrm{Si}, \mathrm{H})$ increases from $285 \mathrm{~Hz}$ in $\mathrm{Pyr}_{3} \mathrm{SiH}$ to $417 \mathrm{~Hz}$ in 3 . These differences can be attributed to an increased s-character of the bonding $\sigma(\mathrm{Si}-\mathrm{H})$ orbital in $\mathbf{3}$, originating from the more acute $\mathrm{N}-\mathrm{Si}-\mathrm{N}$ angles that increases the p-character of the hybrid orbitals involved in $\mathrm{Si}-\mathrm{N}$ bonding. In agreement with this interpretation, the geometry around silicon in $\mathbf{3}$ resembles more that of the silyl ligand derived from $\mathrm{Pyr}_{3} \mathrm{SiH}$ in the osmium complex $[\mathrm{Os}(\mathrm{Si}-$ $\left.\left.\mathrm{Pyr}_{3}\right)(\mathrm{H})(\mathrm{CO})_{2}\left(\mathrm{PPh}_{3}\right)_{2}\right]$, which displays $\mathrm{N}-\mathrm{Si}-\mathrm{N}$ angles of $99.5(3)^{\circ}$, $100.3(3)^{\circ}$, and $101.1(3)^{\circ}$, and $\mathrm{N}-\mathrm{Si}$ bond lengths of $1.770(7)$, 1.787(7), and 1.788(7) $\AA$ (Table 1).

\begin{tabular}{|c|c|c|c|}
\hline & 3 & $\mathrm{Pyr}_{3} \mathrm{SiH}^{[1]}$ & {$\left[\left(\mathrm{PPh}_{3}\right)_{2}(\mathrm{CO})_{2} \mathrm{Os}(\mathrm{H}) \mathrm{Si}(\mathrm{Pyr})_{3}\right]^{[1]}$} \\
\hline \multirow{3}{*}{$\mathrm{Si}-\mathrm{N}[\AA]$} & $1.7660(10)$ & $1.711(4)$ & $1.770(7)$ \\
\hline & $1.7738(11)$ & $1.735(4)$ & $1.787(7)$ \\
\hline & $1.7760(11)$ & $1.740(4)$ & $1.788(7)$ \\
\hline \multirow[t]{3}{*}{$\mathrm{N}-\mathrm{Si}-\mathrm{N}\left[^{\circ}\right]$} & $100.84(5)$ & $106.8(2)$ & $99.5(3)$ \\
\hline & $101.47(5)$ & $107.3(2)$ & $100.3(3)$ \\
\hline & $101.99(5)$ & $112.8(2)$ & 101.1(3) \\
\hline
\end{tabular}

The small N-Si-N angles suggest higher s-character, with concomitant higher acidity of $\mathrm{H}$, in the $\mathrm{Si}-\mathrm{H}$ bond, obeying Bent's rule. This interpretation was confirmed in silico by DFT calculations at the B3LYP/6-31G $(d, p)$ level of theory. The calculated average angles of $103^{\circ}$ and $109^{\circ}$ for 3 and $\mathrm{Pyr}_{3} \mathrm{SiH}$, respective$l y$, reproduce the experimental trend accurately. At the same time, the $\mathrm{Si}-\mathrm{H}$ bond length decreases from $1.472 \AA$ in $\mathrm{Pyr}_{3} \mathrm{SiH}$ to $1.443 \AA$ in 3 . Natural bonding orbital analysis ${ }^{[61]}$ of these compounds shows an increase in p-character for the Si-centered natural hybrid orbital $(\mathrm{NHO})$ involved in $\mathrm{Si}-\mathrm{N}$ bonding from $\mathrm{sp}^{3.31}$ in $\mathrm{Pyr}_{3} \mathrm{SiH}$ to $\mathrm{sp}^{3.76}$ in $\mathbf{3}$. In line with this, the $\mathrm{p}$-character in the Si hybrid orbital involved in $\mathrm{Si}-\mathrm{H}$ bonding decreas- 
es ( $\mathrm{sp}^{2.11}$ in $\mathrm{Pyr}_{3} \mathrm{SiH} \mathrm{sp}^{1.59}$ in 3). Consequently, the hydrogen acquires more $\mathrm{H}^{+}$character in 3 , as shown by the natural charges on hydrogen (NC): -0.204 in $\mathrm{Pyr}_{3} \mathrm{SiH}$ and -0.154 in 3. This accumulation of positive charge on the hydrogen might facilitate subsequent deprotonation.

The trisubstituted hydrosilane $\mathbf{3}$ is thermally stable, and no sign of hydrosilylation was observed even after heating a sample at $100^{\circ} \mathrm{C}$ for $70.5 \mathrm{~h}$. This is likely due to steric congestion preventing imine coordination $(\mathrm{N}-\mathrm{Si}$ distances of ca. $2.82 \AA$ in the solid state) and access to the $\mathrm{Si}-\mathrm{H}$ bond. To test this hypothesis, we investigated analogous chemistry with the iminopyrrole compound Mes IMPH, in which the diisopropylphenyl is replaced by the less sterically demanding mesityl group. Exposing three equivalents of ${ }^{\mathrm{Mes}} \mathrm{IMPH}$ to $\mathrm{HSiCl}_{3}$ in the presence of $\mathrm{NEt}_{3}$ resulted in the formation of the trisubstituted silane 4 , in which one of the imine functionalities has been hydrosilylated (Scheme 3). The X-ray crystal structure of 4 (Figure 6) reveals a pentacoordinated compound with a distort-

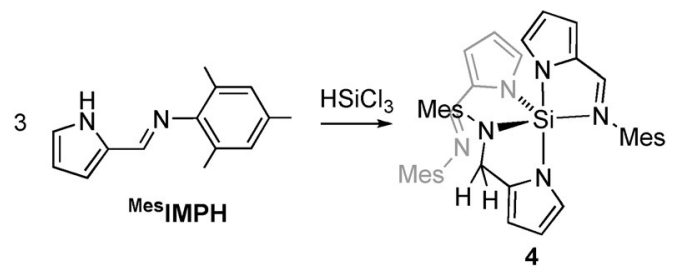

Scheme 3. Silylation reaction of ${ }^{\mathrm{Mes}} \mathrm{MPH}$ to give 4 .

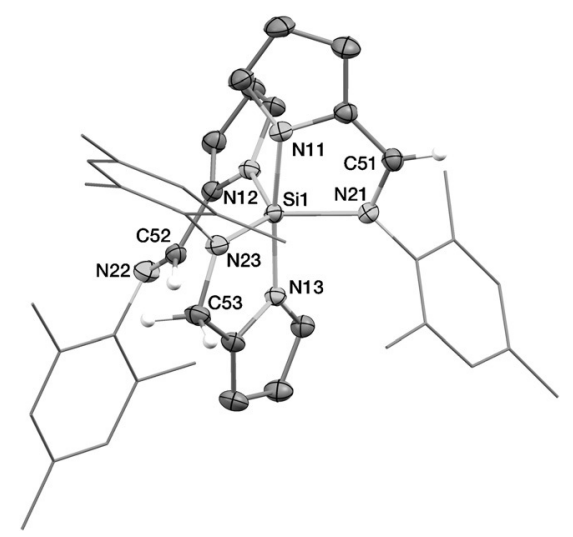

Figure 6. Molecular structure of $\mathbf{4}$ in the crystal. Ellipsoids are set at $50 \%$ probability; hydrogen atoms other than $\mathrm{N}=\mathrm{CH}$ and $\mathrm{N}-\mathrm{CH}_{2}$ are omitted and aryl groups are shown as wireframe for clarity. Selected bond distances $[\AA]$ and angles [ ${ }^{\circ}$ ]: N21-C51 1.3244(15), N22-C52 1.2775(15), N23-C53 1.4647(15); N12-Si1-N21 110.59(4).

ed TBP geometry $(\tau=0.79),{ }^{[47]}$ in which one of the imine moieties is not coordinated to the Si center. The apical positions are occupied by two pyrrole substituents, as was also observed for compound 2 . The structure of compound 4 , however, does not suffer from the same disorder as that of $\mathbf{2}$ and the hydrosilylation site is clearly identified by a $\mathrm{C}-\mathrm{N}$ bond length of $1.4647(15) \AA$, typical for a single bond, ${ }^{[62]}$ and the presence of a $\mathrm{CH}_{2}$ and two $\mathrm{CH}$ groups, with all the hydrogen atoms located in the difference Fourier maps. The coordinated $\mathrm{C}=\mathrm{N}$ bond $(1.3244(15) \AA)$ is slightly longer than the non-coordinated bond (1.2775(15) $\AA)$, indicating a somewhat weaker bond.

The ${ }^{1} \mathrm{H}$ NMR spectrum of crystalline material of $\mathbf{4}$ reveals nine different pyrrole- $\mathrm{H}$ resonances, indicating three different substituents around silicon. Furthermore, two doublet signals, which integrate to a total of $2 \mathrm{H}$, were observed at 4.02 and $4.10 \mathrm{ppm}$. As seen in compound 2 , this double doublet signal is characteristic for a hydrosilylated imine $\left(\mathrm{CH}_{2}-\mathrm{N}\right)$ with diastereotopic hydrogen atoms. Moreover, a singlet resonance was observed in the proton-coupled ${ }^{29} \mathrm{Si}$ NMR spectrum at $\delta=$ $-120.4 \mathrm{ppm}$. In ${ }^{13} \mathrm{C}$ NMR spectrum, two resonances for imine carbon atoms were observed at $\delta=156.0$ and $160.4 \mathrm{ppm}$ and one resonance for $\mathrm{CH}_{2}$ at $\delta=48.0 \mathrm{ppm}$. From the HMQC spectrum, the resonances for the two imine $\mathrm{CH}$ groups in the ${ }^{1} \mathrm{H}$ NMR spectrum could be deduced ( $\delta=6.55$ and $6.67 \mathrm{ppm}$ ). Interestingly, in the ${ }^{1} \mathrm{H}$ NMR spectrum, all resonances for the pyrrole and methyl hydrogen atoms appear slightly broadened due to fluxional processes on the NMR timescale. In a low-temperature measurement at $-25^{\circ} \mathrm{C}$, the resonances appear sharp (Supporting Information, Figure $\mathrm{S} 30$ ), whereas at $70^{\circ} \mathrm{C}$ the signals coalesce into fewer, broader signals. Most notably, the $\mathrm{CH}_{2}$ resonance broadens, hence the two hydrogen atoms are no longer diastereotopic (Supporting Information, Figure S28). This means that the process makes the two non-hydrosilylated substituents equivalent and is therefore likely to consist of reversible detachment of the bound imine.

From ${ }^{1} \mathrm{H}$ NMR spectroscopic analysis it was clear that a second, minor species was present; $0.16 \mathrm{ppm}$ downfield of the major $\mathrm{CH}_{2}$ signal a second double doublet signal appeared with an intensity of $32 \%$ relative to the major $\mathrm{CH}_{2}$ signal at $25^{\circ} \mathrm{C}$. This minor species is in equilibrium with $\mathbf{4}$ in solution as substantiated by EXSY NMR spectroscopic analysis at $-10^{\circ} \mathrm{C}$, which shows cross peaks for protons that mutually exchange. For 4 and the minor species, it shows exchange between the $\mathrm{CH}_{2}$ signals at $\delta=3.96$ (4, major) and 4.23 (minor) ppm and between the imine signals mutually. Following from the proposed reversible detachment of the non-hydrosilylated substituents, for the minor compound we propose an imine-detached tetrahedral structure, which has not been identified due to the low equilibrium concentration.

Compound 4 shows the propensity of $\left({ }^{\mathrm{Ar}} \mathrm{IMP}\right)_{3} \mathrm{SiH}$ to undergo the intramolecular hydrosilylation process that was previously observed in silane $\mathbf{2}$, but not in silane $\mathbf{3}$. In that respect, the occurrence of hydrosilylation in compound $\mathbf{4}$ shows that, indeed, rather than electronics, steric interactions inhibit this process in the more bulky compound 3 . Compound 4 is an unusual all-N pentacoordinate silane, precedented only by azasilatranes, which consist of a tetradentate, tri-anionic ligand and a second monodentate $\mathrm{N}$-ligand $\left(\mathrm{NCS}^{-}\right.$or $\mathrm{N}_{3}{ }^{-}$) bound to silicon. ${ }^{[63]}$

\section{Hydrosilylation reaction in monosubstituted silanes and identification of hexacoordinate intermediate species 6}

Intramolecular hydrosilylation processes related to those described above have been reported recently by Lippe et al. ${ }^{[41]}$ 
and by Novák et al. ${ }^{[42]}$ In view of the growing interest in $\mathrm{N}$ bound silanes as precursors for silicon(II) compounds, it is of interest to understand the factors controlling this generally undesired reactivity. Hence, we set out to further investigate this process. First, a $95 \mathrm{~mm}$ solution of the monosubstituted compound 1 a with mesitylene as an internal standard was heated to $70^{\circ} \mathrm{C}$ in a closed J-Young NMR tube and the hydrosilylation reaction was monitored by ${ }^{1} \mathrm{H} N M R$ spectroscopy. Over a period of $260 \mathrm{~h}$, very slow conversion into a hydrosilylated species (ca. 5\%) was observed; this species showed two strongly mutually coupled doublets at $\delta=4.17$ and $4.38 \mathrm{ppm}$ for the methylene protons, but could not be identified otherwise. Concomitantly, the low-boiling $\mathrm{HSiCl}_{2} \mathrm{Me}$ was formed, as evidenced by a characteristic quartet for $\mathrm{Si}-\mathrm{H}$ at $\delta=5.21 \mathrm{ppm}$ and doublet for $\mathrm{Si}-\mathrm{CH}_{3}$ at $\delta=0.18 \mathrm{ppm} \quad\left({ }^{3} J(\mathrm{H}, \mathrm{H})=2.3 \mathrm{~Hz}\right)$. Given the low conversion over a long time for $1 \mathrm{a}$, compound $1 \mathrm{~b}$ was subjected to the same conditions; the hydrosilylation reaction in an $80 \mathrm{~mm} \mathrm{C}_{6} \mathrm{D}_{6}$ solution of $\mathbf{1} \mathbf{b}$ was monitored by ${ }^{1} \mathrm{H}$ NMR spectroscopy. Over a period of $60 \mathrm{~h}$, the concentration of $1 \mathbf{b}$ decreased to about $20 \mathrm{~mm}$ with concomitant appearance of three new species (Scheme 4; Supporting Information,

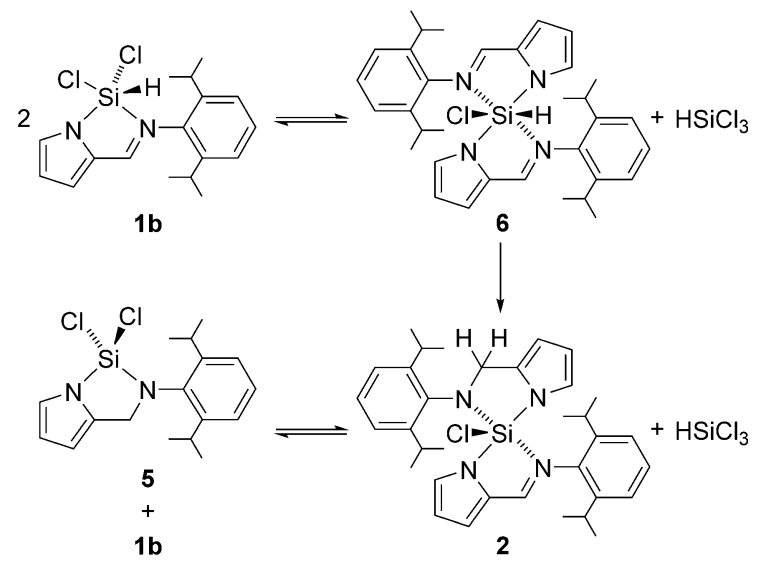

Scheme 4. Proposed pathway for the hydrosilylation in $\mathbf{1} \mathbf{b}$.

Figure S45). The two minor products were straightforwardly assigned: the imino/amino compound 2 (ca. $12 \mathrm{~mm}$ ) was identified by comparison with an isolated sample and $\mathrm{HSiCl}_{3}$ (ca. $6 \mathrm{~mm}$ ) by a signal at $5.53 \mathrm{ppm}$ in the ${ }^{1} \mathrm{H}$ NMR spectrum with ${ }^{29} \mathrm{Si}$ satellites $\left({ }^{1} \mathrm{~J}(\mathrm{Si}, \mathrm{H})=372 \mathrm{~Hz}\right)$. The lower concentration of the latter can be ascribed to loss to the headspace $\left(T_{b}=32^{\circ} \mathrm{C}\right)$. The major product $(40 \mathrm{~mm})$ is assigned as the aminopyrrolide compound 5 (Scheme 4), formed by intramolecular hydrosilylation from $\mathbf{1} \mathbf{b}$, on the basis of NMR data. In particular, a diagnostic ${ }^{1} \mathrm{H}$ NMR resonance at $\delta=4.20 \mathrm{ppm}$ shows the presence of the $\mathrm{N}-\mathrm{CH}_{2}$ moiety, and a singlet ${ }^{29} \mathrm{Si}$ NMR resonance at $\delta=$ $-36.5 \mathrm{ppm}$ indicates a tetracoordinate environment around silicon and the absence of an $\mathrm{Si}-\mathrm{H}$ bond. In agreement with this assignment, DFT calculations predict a chemical shift of $\delta=$ $-31.2 \mathrm{ppm}$ for $\mathbf{5}$ (see the Supporting Information for details, including method calibration in Table S2).

This reaction was monitored by ${ }^{1} \mathrm{H}$ NMR spectroscopic analysis and the evolution of the concentration for different com-

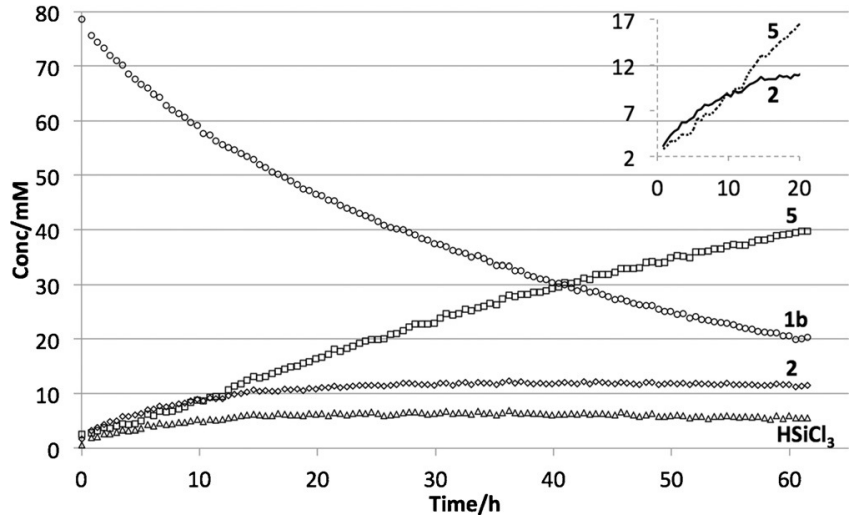

Figure 7. Reaction composition determined through internal standard (mesitylene) at $70^{\circ} \mathrm{C}$; average integral of the isolated resonances relative to IS. Inset shows an expansion of the early stages of the reaction ( $t=0-20 \mathrm{~h}$ ).

pounds is plotted in Figure 7. The concentration of $1 \mathbf{b}$ decreased throughout the reaction whereas that of $\mathbf{5}$ increased steadily. In contrast, the concentrations of both 2 and $\mathrm{HSiCl}_{3}$ increased more rapidly than $\mathbf{5}$ at the early stages (inset in Figure 7) but reach a plateau after approximately $20 \mathrm{~h}$, suggesting that these species may be intermediates in the overall process. To account for this reaction profile, we propose the reaction pathway shown in Scheme 4. First, a ligand redistribution process disproportionates two equivalents of compound $1 \mathbf{b}$ into both $\mathrm{HSiCl}_{3}$ and the disubstituted compound 6, which then undergoes an intramolecular hydrosilylation reaction to form compound 2. A subsequent ligand redistribution process then finally releases one equivalent of the product $\mathbf{5}$ and one equivalent of $\mathbf{1} \mathbf{b}$ from $\mathbf{2}$ and $\mathrm{HSiCl}_{3}$.

The individual steps in this proposed reaction scheme were investigated in a series of stoichiometric experiments. First, the feasibility of the product-releasing step was demonstrated by addition of a substoichiometric amount of $\mathrm{HSiCl}_{3}$ to a solution of 2 ; after $2.5 \mathrm{~h}$ at $70^{\circ} \mathrm{C}$, this yielded both $\mathbf{1 ~ b}$ and $\mathbf{5}$, along with remaining 2 in a 21:36:43\% ratio (1 b/5/2), in which the concentration of $\mathbf{5}$ increased over time to reach a ratio of $2: 66: 32 \%$ after $20.5 \mathrm{~h}$ at $70^{\circ} \mathrm{C}$. We then sought to observe the postulated disubstituted hydrosilane 6 , which was not detected under the reaction conditions. This was achieved by reacting $1 \mathbf{b}$ with a slight excess of DippIMPLi in a mixture of $\left[D_{8}\right]$ toluene and $\left[D_{8}\right]$ THF at room temperature, affording a solution containing a mixture of $\mathbf{6}$ and the trisubstituted $\mathbf{3}$ after filtration. These conditions were chosen so that the main byproduct in solution is the highly symmetrical 3, thus limiting peak overlap. The ${ }^{29} \mathrm{Si}$ NMR spectrum of 6 at $-60^{\circ} \mathrm{C}$ exhibits a doublet at $\delta=-168.4 \mathrm{ppm}\left({ }^{1} J(\mathrm{Si}, \mathrm{H})=287 \mathrm{~Hz}\right)$, indicating a hexacoordinate structure containing a $\mathrm{Si}-\mathrm{H}$ bond. The ${ }^{1} \mathrm{H}$ NMR spectrum of 6 is very broad at room temperature, indicating the presence of fluxional processes that may involve reversible detachment of an imine moiety, but a sharp spectrum can be obtained at $-60^{\circ} \mathrm{C}$. This result shows that the compound has low symmetry, as evidenced by four individual signals for the inequivalent $i \operatorname{Pr} \mathrm{CH}$ groups, two signals for imine moieties, and one for the $\mathrm{Si}-\mathrm{H}$ bond $(\delta=5.83 \mathrm{ppm})$, identified 
by flanking ${ }^{29} \mathrm{Si}$ satellites and a correlation with the silicon resonance in $\mathrm{Si}, \mathrm{H}$ HSQC. Compound 6 partially converts into compound 2 when the mixture is heated to $70^{\circ} \mathrm{C}$ over a period of $16 \mathrm{~h}$. However, if the reaction is conducted with an excess of silane instead of ${ }^{D i p p} I M P L i$, the hydrosilylation process is faster (Supporting Information, Figure S43). Compound 6 could also be synthesized by adding $\mathrm{HSiCl}_{3}$ to two equivalents of ${ }^{\mathrm{Dipp}} \mathrm{IMPLi}$ at $-78^{\circ} \mathrm{C}$ in THF, but it could not be isolated from the mixtures containing $\mathbf{1} \mathbf{b}$ and $\mathbf{3}$.

The low symmetry found in low-temperature ${ }^{1} \mathrm{H}$ NMR spectra prompted us to investigate the conformation of 6 by density functional theory calculations including NMR shifts, $J$-coupling values, and free-energy calculations. These calculations were conducted on three relevant low-symmetry structures as well as with one higher symmetry structure: 1) cis-all (Scheme 5, left) featuring the pyrroles, imines, and $\mathrm{H}$ and $\mathrm{Cl}$
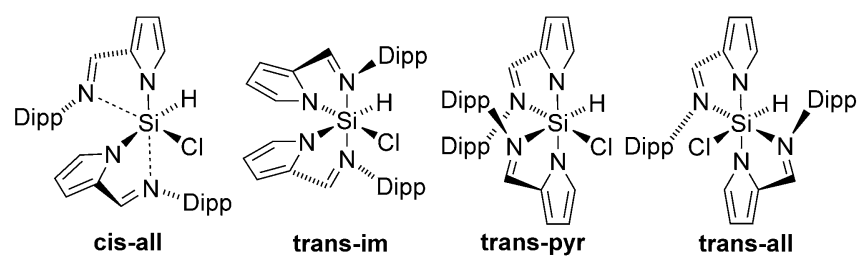

Scheme 5. Calculated isomers of hexacoordinate 6 .

mutually cis to each other; 2) trans-im (Scheme 5, middle-left) having mutual cis pyrrole, and mutual trans imine groups; 3) trans-pyr (Scheme 5, middle-right) having mutual cis for imine, and mutual trans for pyrrole; and 4) the $C_{2}$-symmetric trans-all (Scheme 5, right). These calculations, which are summarized in Table 2, show that only trans-pyr is consistent with

\begin{tabular}{|c|c|c|c|c|}
\hline & $\begin{array}{l}\delta \\
{[p p m \text { vs. TMS] }}\end{array}$ & $\begin{array}{l}\text { Deviation } \\
{[p p m]}\end{array}$ & $\begin{array}{l}{ }^{1} J(\mathrm{Si}, \mathrm{H}) \\
{[\mathrm{Hz}]}\end{array}$ & $\begin{array}{l}\text { Deviation } \\
{[\mathrm{Hz}]}\end{array}$ \\
\hline observed & -168 & - & $288^{[\mathrm{a}]}$ & - \\
\hline cis-all & -52 & 116 & -419 & 131 \\
\hline trans-im & -169 & -1 & -361 & 72 \\
\hline trans-pyr & -163 & 5 & -307 & 19 \\
\hline trans-all & -176 & -8 & -309 & 21 \\
\hline
\end{tabular}

the experimental NMR data: only half of the number of signals for the substituents can be expected in trans-all, the ${ }^{1} J(\mathrm{Si}, \mathrm{H})$ coupling calculated for trans-im deviates significantly from that observed and the cis-all conformer could not be optimized as a hexacoordinate structure. Additionally, a hexacoordinate structure can be imagined with the $\mathrm{H}$ and $\mathrm{Cl}$ substituent trans with respect to each other and the imine and pyrrole groups mutually cis. This structure cannot be optimized because both dipp groups point towards each other in such a structure and experience too much steric repulsion. The calculated energy differences between the three optimized hexacoordinated conformers are $\Delta \Delta G_{213 \mathrm{~K}}=1.8 \mathrm{kcalmol}^{-1}$ for trans-im and $\Delta \Delta G_{213 \mathrm{k}}=3.6 \mathrm{kcalmol}^{-1}$ for trans-pyr compared with the lowest energy structure trans-all. Given that the analytical data correspond only to the trans-pyr conformer, this energy difference is ascribed to the error in the calculations.

The intramolecular hydrosilylation reaction of $\mathbf{1 b}$ to $\mathbf{5}$, taking place over more than $60 \mathrm{~h}$ at $70^{\circ} \mathrm{C}$, should, in principle, not have hampered the isolation of $\mathbf{1} \mathbf{b}$. Nevertheless, analysis of the reaction mixture obtained after the reaction of one equivalent of ${ }^{D i p p} I M P H$ with $\mathrm{HSiCl}_{3}$ in the presence of $\mathrm{NEt}_{3}$ at room temperature (see above) revealed the presence of both 2 and 5, suggesting that this hydrosilylation process may be catalyzed by one of the components of the reaction mixture. Furthermore, monitoring in solution a sample of $\mathbf{1} \mathbf{b}$ that had been obtained from the reaction of ${ }^{\text {Dipp }}$ IMPLi with $\mathrm{HSiCl}_{3}$ without thorough purification by crystallization (ca. $98 \%$ purity by ${ }^{1} \mathrm{H}$ NMR spectroscopic analysis) revealed significantly faster hydrosilylation; conversion of $35 \%$ versus $3 \%$ in $73 \mathrm{~h}$ at room temperature and $80 \%$ versus $37 \%$ in $17 \mathrm{~h}$ at $70^{\circ} \mathrm{C}$. The lower reaction rate of the pure sample suggests the influence of a catalytically competent species in the crude product. Catalytic entities potentially present in the nonpurified compound are trace amounts of chloride $\left(\mathrm{NEt}_{3} \mathrm{HCl}, \mathrm{LiCl}\right)$ or base ( $\mathrm{NEt}_{3}$, Dipp IMP). To investigate the influence of the chloride anion, approximately $5 \mathrm{~mol} \%$ tetrabutylammonium chloride $\left(\mathrm{Bu}_{4} \mathrm{NCl}\right)$ was added to a $\mathrm{C}_{6} \mathrm{D}_{6}$ solution of isolated $\mathbf{1} \mathbf{b}$. This resulted in a drastic increase in reaction rate: viz. $23 \%$ conversion in $5.5 \mathrm{~h}$ at room temperature compared with no measurable conversion for a sample of purified $\mathbf{1} \mathbf{b}$. Conversely, addition of one equivalent of $\mathrm{NEt}_{3}$ seems to inhibit the reaction so that only minute conversion was observed after $16 \mathrm{~h}$ at $70^{\circ} \mathrm{C}$. These results indicate that the chloride anion is an efficient catalyst for the described hydrosilylation process in $\mathbf{1} \mathbf{b}$. In contrast, $\mathrm{Bu}_{4} \mathrm{NCl}$ did not induce hydrosilylation in silanes $\mathbf{1} \mathbf{a}$ and $\mathbf{3}$ upon heating to $70^{\circ} \mathrm{C}$ for $23 \mathrm{~h}$.

The mode of action of the chloride anion was not investigated in detail. It is plausible that transient chloride coordination to silicon (for example, substituting an imine ligand in intermediate 6) increases the nucleophilicity of the $\mathrm{Si}-\mathrm{H}$ bond, in line with the observation by Yamamura et al. that catalytic amounts of $\mathrm{F}^{-}$facilitate the intramolecular hydrosilylation of an azobenzene derivative. ${ }^{[64]}$ Alternatively, it seems likely that some of the required ligand exchange steps would be susceptible to nucleophilic catalysis. ${ }^{[53,65,66]}$

\section{Conclusions}

During our attempts to synthesize iminopyrrolyl hydrosilanes, we found hydrosilylation to occur in several cases. The penta-

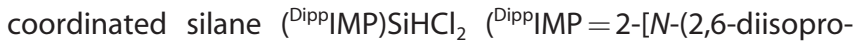
pylphenyl)iminomethyl]pyrrolide) proved to undergo intramolecular hydrosilylation. This reaction is catalyzed by the chloride anion and involves hexa- (6) and pentacoordinated (2) disubstituted silanes formed by ligand redistribution as intermediates. In contrast, the pentacoordinated monosubstituted chloromethyl silane was much more reluctant to undergo this 
process. Hence, the hydrosilylation reaction can be influenced by tuning the electron density on silicon. This process can also be influenced by steric effects, which was shown with the tetracoordinated trisubstituted silane ( $\left.{ }^{\mathrm{Dipp}} \mathrm{IMP}\right)_{3} \mathrm{SiH} 3$, in which hydrosilylation is completely inhibited. Reducing the size of the aryl groups from 2,6-diisopropylphenyl to mesityl restored hydrosilylation reactivity and yielded the pentacoordinated trisubsituted all-N silane 4, indicating that trisubstituted silanes are also susceptible to hydrosilylation.

The obtained knowledge of the conditions favoring and disfavoring the imine hydrosilylation reaction complements existing approaches in which the imine moiety is passivated by incorporation in a conjugated $\pi$-system; that is, aromatic heterocycles ${ }^{[67-72]}$ and amidinate/guanidinate compounds. ${ }^{[59,73-76]}$ This is anticipated to aid in the controlled synthesis of N-substituted silicon compounds as precursors for silicon(II) ligands. Research in this direction is ongoing in our laboratories.

\section{Experimental Section}

All reactions involving silicon-containing compounds were conducted under an $\mathrm{N}_{2}$ atmosphere by using standard glovebox or Schlenk techniques. Diethyl ether, $n$-hexane, toluene, and acetonitrile were dried with an MBRAUN MB SPS-79 system, degassed by bubbling with $\mathrm{N}_{2}$ for $30 \mathrm{~min}$, and stored over molecular sieves in a glovebox. THF was distilled from benzophenone/ $\mathrm{Na}$, degassed by bubbling with $\mathrm{N}_{2}$ for $30 \mathrm{~min}$, and stored over molecular sieves in a glovebox. All chemicals were obtained commercially and used as received unless stated otherwise. Dichloromethylsilane was purchased from Fluka; pyrrole-2-carboxaldehyde (99\%), $n$-butyllithium (1.6 $\mathrm{M}$ in hexanes), and triethylamine $(99 \%)$ were purchased from Acros; trichlorosilane (99\%), 2,4,6-trimethylaniline (98\%), tetrabutylammonium chloride ( $\geq 97 \%$, anhydrous), and 2,6-diisopropylaniline $(92 \%)$ were purchased from Sigma-Aldrich. Both silanes were transferred into and stored in a Teflon stoppered Schlenk flask upon arrival. Triethylamine was degassed by bubbling with $\mathrm{N}_{2}$ for $30 \mathrm{~min}$ and stored over molecular sieves. All NMR chemical shifts are reported relative to TMS with the residual solvent signal as internal standard. ${ }^{[77]}$ All NMR experiments involving silicon-containing compounds were conducted in J-Young NMR tubes under an $\mathrm{N}_{2}$ atmosphere. For compound $5, \mathrm{Cr}(\mathrm{acac})_{3}$ was used as a paramagnetic relaxation agent for ${ }^{29} \mathrm{Si}$ NMR spectroscopy. Elemental analysis was conducted by the Mikroanalytisches Laboratorium Kolbe. The substituents ${ }^{\mathrm{Dipp}} \mathrm{IMPH}_{1}^{[45]}{ }^{\mathrm{Dipp}} \mathrm{IMPLi},{ }^{[78]}$ and ${ }^{M e s}{ }_{M P H}{ }^{[79]}$ were prepared according to reported procedures.

\section{Computational methods}

All DFT calculations were performed with Gaussian 09. ${ }^{[80]}$ Geometry optimizations were performed by using the B3LYP functional with $6-31 G(d, p)$ as the basis set on all atoms. A frequency calculation was performed on all converged geometries to verify that they were minima. For transition-state calculations, one imaginary frequency was obtained. NMR calculations at the B3LYP/IGLO-III level were performed after geometry optimization at the B3LYP/6$31 \mathrm{G}(\mathrm{d}, \mathrm{p})$ level, for coupling constants using the "spinspin" option. For NBO calculations, the NBO6 program up to the NLMO basis set was used. ${ }^{[61]}$

\section{X-ray crystal structure determinations}

$X$-ray reflections were measured with a Bruker Kappa Apexll diffractometer with sealed tube and Triumph monochromator $(\lambda=$ $0.71073 \AA$ ). The intensities were integrated with the Eval15 software. ${ }^{[81]}$ Multiscan absorption correction and scaling was performed with SADABS. ${ }^{[82]}$ The structures were solved by Patterson superposition methods using SHELXT. ${ }^{[83]}$ Least-squares refinement was performed with SHELXL-2013 or SHELXL-2014 ${ }^{[84]}$ against $F^{2}$ of all reflections. Non-hydrogen atoms were refined freely with anisotropic displacement parameters. Hydrogen atoms were located in difference Fourier maps (compounds $\mathbf{1}$ a and 4) or introduced in calculated positions (compounds 2 and 3 ). Geometry calculations and checking for higher symmetry was performed with the PLATON program. ${ }^{[85]}$

CCDC 1436231 (1 a), 1436232 (2), 1436233 (3), and 1436234 (4) contain the supplementary crystallographic data for this paper. These data are provided free of charge by The Cambridge Crystallographic Data Centre.

\section{Silane synthesis}

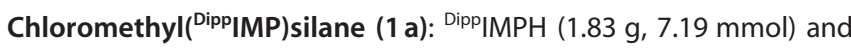
$\mathrm{NEt}_{3}(1.5 \mathrm{~mL}, 10.76 \mathrm{mmol})$ were dissolved in THF $(25 \mathrm{~mL})$ and cooled to $-78^{\circ} \mathrm{C}$, then $\mathrm{HSiMeCl}_{2}(0.9 \mathrm{~mL}, 8.78 \mathrm{mmol})$ was added rapidly. The mixture was stirred for $1 \mathrm{~h}$ at $-78^{\circ} \mathrm{C}$, during which the clear solution became turbid. Subsequently, the mixture was stirred for $16 \mathrm{~h}$ at RT. $n$-Hexane $(75 \mathrm{~mL})$ was added and the solids were filtered off and extracted with $n$-hexane $(2 \times 10 \mathrm{~mL})$. The filtrate was combined with the $n$-hexane extracts and freed of solvent in vacuo to give $1 \mathrm{a}(2.2 \mathrm{~g}, 6.6 \mathrm{mmol}, 92 \%)$ as an off-white powder that was pure enough for further use. Crystals suitable for X-ray analysis were grown by vapor diffusion of $n$-hexane into a solution of $1 \mathrm{a}$ in diethyl ether. ${ }^{1} \mathrm{H} N M R\left(400 \mathrm{MHz}, \mathrm{C}_{6} \mathrm{D}_{6}, 25^{\circ} \mathrm{C}\right): \delta=8.19$ (ddd ${ }^{4} J(\mathrm{H}, \mathrm{H})=0.9 \mathrm{~Hz},{ }^{4} J(\mathrm{H}, \mathrm{H})=1.3 \mathrm{~Hz},{ }^{3} J(\mathrm{H}, \mathrm{H})=2.6 \mathrm{~Hz}, 1 \mathrm{H}$; pyrrole- $\left.\mathrm{H} 3\right)$, 7.46 (app. t, $\left.{ }^{4} J(\mathrm{H}, \mathrm{H})=0.9 \mathrm{~Hz},{ }^{4} J(\mathrm{H}, \mathrm{H})=0.9 \mathrm{~Hz}, 1 \mathrm{H} ; \mathrm{N}=\mathrm{CH}\right), 7.07,7.00$ $\left(\mathrm{AB}_{2}\right.$ pattern, $J_{\mathrm{AB}}=7.9 \mathrm{~Hz}, 3 \mathrm{H}$; $\left.\mathrm{Ar}-\mathrm{H}\right), 6.56\left(\mathrm{dd},{ }^{4} \mathrm{~J}(\mathrm{H}, \mathrm{H})=1.3 \mathrm{~Hz}\right.$, ${ }^{3} \mathrm{~J}(\mathrm{H}, \mathrm{H})=3.6 \mathrm{~Hz}, 1 \mathrm{H}$; pyrrole- $\left.\mathrm{H5}\right), 6.30\left(\mathrm{dd},{ }^{3} \mathrm{~J}(\mathrm{H}, \mathrm{H})=2.6 \mathrm{~Hz},{ }^{3} \mathrm{~J}(\mathrm{H}, \mathrm{H})=\right.$ $3.6 \mathrm{~Hz}, 1 \mathrm{H}$; pyrrole-H4), 6.16 (br. s, ${ }^{1} \mathrm{~J}(\mathrm{Si}, \mathrm{H})=312 \mathrm{~Hz}, 1 \mathrm{H}$; Si-H), 2.92 $(\mathrm{br}, 1 \mathrm{H} ; i \operatorname{Pr} \mathrm{CH}), 2.56(\mathrm{br}, 1 \mathrm{H} ; i \operatorname{Pr} \mathrm{CH}), 0.99\left(\mathrm{br}, 12 \mathrm{H} ; i \mathrm{Pr}-\mathrm{CH}_{3}\right)$, $0.64 \mathrm{ppm} \quad\left(\mathrm{d}, \quad{ }^{3} \mathrm{~J}(\mathrm{H}, \mathrm{H})=1.7 \mathrm{~Hz}, \quad{ }^{2} J(\mathrm{Si}, \mathrm{H})=8.5 \mathrm{~Hz}, \quad 3 \mathrm{H} ; \quad \mathrm{Si}-\mathrm{CH}_{3}\right)$; ${ }^{13} \mathrm{C}\left\{{ }^{1} \mathrm{H}\right\}$ NMR $\left(100 \mathrm{MHz}, \mathrm{C}_{6} \mathrm{D}_{6}, 25^{\circ} \mathrm{C}\right): \delta=154.8,140.6,137.7,134.2$, 127.6, 124.4, 119.7, 115.2, 28.7 (br), 26.5 (br), 25.4 (br), 24.1 (br) 22.9 (br), $6.11 \mathrm{ppm}\left(\mathrm{Si}-\mathrm{C},{ }^{1} \mathrm{~J}(\mathrm{Si}, \mathrm{C})=84.6 \mathrm{~Hz}\right) ;{ }^{29} \mathrm{Si} \mathrm{NMR}\left(79 \mathrm{MHz}, \mathrm{C}_{6} \mathrm{D}_{6}\right.$, $\left.25^{\circ} \mathrm{C}\right): \delta=-64.9 \mathrm{ppm}\left(\mathrm{dq},{ }^{1} J(\mathrm{Si}, \mathrm{H})=313 \mathrm{~Hz},{ }^{2} \mathrm{~J}(\mathrm{Si}, \mathrm{H})=8 \mathrm{~Hz}\right) ; \quad$ IR (ATR): $\tilde{v}=2211 \mathrm{~cm}^{-1}(\mathrm{Si}-\mathrm{H}), 1648 \mathrm{~cm}^{-1}(\mathrm{C}=\mathrm{N})$; elemental analysis calcd (\%) for $\mathrm{C}_{18} \mathrm{H}_{25} \mathrm{~N}_{2} \mathrm{SiCl}$ : C 64.93, H 7.57, N 8.41; found: C 65.12, H 8.33, N 7.97 .

Crystallographic details: $\mathrm{C}_{18} \mathrm{H}_{25} \mathrm{ClN}_{2} \mathrm{Si} ; \mathrm{F}_{\mathrm{w}}=332.94$; colorless block; $0.43 \times 0.41 \times 0.31 \mathrm{~mm}^{3}$; monoclinic; $P 2_{1} / n$ (no. 14); $a=14.2957(6)$, $b=9.4401(2), \quad c=15.2753(3) \AA, \quad \beta=115.112(1)^{\circ} ; \quad V=1866.59(9) \AA^{3}$; $Z=4 ; \quad D_{\mathrm{x}}=1.185 \mathrm{~g} \mathrm{~cm}^{-3} ; \mu=0.27 \mathrm{~mm}^{-1} ; 31830$ reflections were measured at a temperature of $150(2) \mathrm{K}$ up to a resolution of $(\sin \theta /$ $\lambda)_{\max }=0.65 \AA^{-1} ; 4286$ reflections were unique $\left(R_{\text {int }}=0.014\right)$, of which 4026 were observed $[I>2 \sigma(l)]$. The Si-H hydrogen atom was refined freely with an isotropic displacement parameter. All other $\mathrm{H}$-atoms were refined with a riding model; 208 parameters were

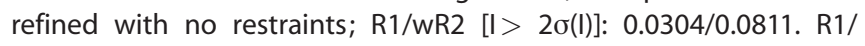
wR2 [all refl.]: $0.0319 / 0.0821$. $S=1.036$; residual electron density between -0.29 and 0.36 e $\AA^{3}$.

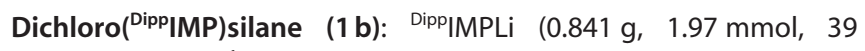
mass $\% \mathrm{Et}_{2} \mathrm{O}$ by ${ }^{1} \mathrm{H}$ NMR spectroscopic analysis) was dissolved in THF $(25 \mathrm{~mL})$ and cooled to $-78^{\circ} \mathrm{C}$, then $\mathrm{HSiCl}_{3}(0.300 \mathrm{~mL}$, $2.97 \mathrm{mmol}$ ) was added rapidly. The mixture was stirred for $45 \mathrm{~min}$ 
and allowed to warm to $0{ }^{\circ} \mathrm{C}$, after which it was freed of solvent in vacuo. The solid residue was extracted in toluene $(10 \mathrm{~mL})$ and freed of solvent in vacuo. This operation was repeated with toluene $(12 \mathrm{~mL})$ to give an orange powder (97\% yield), containing $15 \%$ of hydrosilylated products $\mathbf{2}$ and $\mathbf{5}$, which presumably formed during the evaporation of toluene. The solid was stored in a glovebox at $-35^{\circ} \mathrm{C}$. Pure samples were freshly prepared by crystallization from a saturated $n$-hexane solution at $-35^{\circ} \mathrm{C}$ prior to following experiments to yield spectroscopically pure $1 \mathbf{b}$ as cloudy crystals. ${ }^{1} \mathrm{H}$ NMR $\left(400 \mathrm{MHz}, \mathrm{C}_{6} \mathrm{D}_{6}, 25^{\circ} \mathrm{C}\right): \delta=8.06\left(\mathrm{ddd},{ }^{4} \mathrm{~J}(\mathrm{H}, \mathrm{H})=1.0 \mathrm{~Hz}\right.$, ${ }^{3} J(\mathrm{H}, \mathrm{H})=2.7 \mathrm{~Hz},{ }^{4} J(\mathrm{H}, \mathrm{H})=1.2 \mathrm{~Hz}, 1 \mathrm{H}$; pyrrole- $\left.\mathrm{H} 3\right), 7.30\left(\mathrm{dd},{ }^{4} J(\mathrm{H}, \mathrm{H})=\right.$ $\left.1.0 \mathrm{~Hz},{ }^{4} J(\mathrm{H}, \mathrm{H})=1.8 \mathrm{~Hz}, 1 \mathrm{H} ; \mathrm{N}=\mathrm{CH}\right), 7.08,6.99\left(\mathrm{AB}_{2}\right.$ pattern, $J_{\mathrm{AB}}=$ $7.9 \mathrm{~Hz}, 3 \mathrm{H} ; \mathrm{Ar}-\mathrm{H}), 6.57\left(\mathrm{~d},{ }^{4} J(\mathrm{H}, \mathrm{H})=1.8 \mathrm{~Hz},{ }^{1} J(\mathrm{Si}, \mathrm{H})=385 \mathrm{~Hz}, 1 \mathrm{H}\right.$; SiH), $6.44\left(\mathrm{dd},{ }^{3} \mathrm{~J}(\mathrm{H}, \mathrm{H})=3.6 \mathrm{~Hz},{ }^{3} \mathrm{~J}(\mathrm{H}, \mathrm{H})=1.2 \mathrm{~Hz}, 1 \mathrm{H}\right.$; pyrrole- $\left.H 5\right), 6.16$ $\left(\mathrm{dd},{ }^{3} \mathrm{~J}(\mathrm{H}, \mathrm{H})=2.7 \mathrm{~Hz},{ }^{3} \mathrm{~J}(\mathrm{H}, \mathrm{H})=3.6 \mathrm{~Hz}, 1 \mathrm{H}\right.$; pyrrole- $\mathrm{H} 4$ ), 2.83 (sept, $\left.{ }^{3} J(\mathrm{H}, \mathrm{H})=6.8 \mathrm{~Hz}, 2 \mathrm{H} ; i \operatorname{Pr} \mathrm{CH}\right), 1.09\left(\mathrm{~d},{ }^{3} \mathrm{~J}(\mathrm{H}, \mathrm{H})=6.8 \mathrm{~Hz}, 6 \mathrm{H} ; i \operatorname{Pr}-\mathrm{CH}_{3}\right)$, $0.83 \mathrm{ppm}\left(\mathrm{d},{ }^{3} \mathrm{~J}(\mathrm{H}, \mathrm{H})=6.9 \mathrm{~Hz}, 3 \mathrm{H} ; i \operatorname{Pr}-\mathrm{CH}_{3}\right) ;{ }^{13} \mathrm{C}\left\{{ }^{1} \mathrm{H}\right\} \mathrm{NMR}(100 \mathrm{MHz}$, $\left.\mathrm{C}_{6} \mathrm{D}_{6}, 25^{\circ} \mathrm{C}\right): \delta=154.9,143.6,139.2,137.7,132.9,128.6,124.6$, 121.3, 116.7, 29.1, 26.3, $23.4 \mathrm{ppm}$; ${ }^{29} \mathrm{Si} \operatorname{NMR}\left(79 \mathrm{MHz}, \mathrm{C}_{6} \mathrm{D}_{6}, 25^{\circ} \mathrm{C}\right)$ : $\delta=-92.7 \mathrm{ppm} \quad\left({ }^{1} J(\mathrm{Si}, \mathrm{H})=385 \mathrm{~Hz}\right) ; \quad$ IR $\quad($ ATR $): \quad \tilde{v}=2209 \quad(\mathrm{Si}-\mathrm{H})$, $1650 \mathrm{~cm}^{-1}(\mathrm{C}=\mathrm{N})$; elemental analysis calcd (\%) for $\mathrm{C}_{17} \mathrm{H}_{22} \mathrm{Cl}_{2} \mathrm{~N}_{2} \mathrm{Si}$ : C 57.78, H 6.28, N 7.93; found: C 57.99, H 5.91, N 7.85.

Alternative synthesis of dichloro( ${ }^{\text {(ipp IMP) }}$ silane (1 b) without

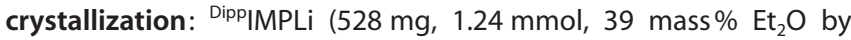
${ }^{1} \mathrm{H}$ NMR spectroscopic analysis) was dissolved in THF $(25 \mathrm{~mL})$ and cooled to $-78^{\circ} \mathrm{C}$, then $\mathrm{HSiCl}_{3}(0.300 \mathrm{~mL}, 2.97 \mathrm{mmol})$ was added swiftly. The mixture was stirred for $45 \mathrm{~min}$ and allowed to slowly warm to $-30^{\circ} \mathrm{C}$ in a beaker containing the cold acetone from the dry-ice bath. The cooling was removed and the mixture was allowed to warm to $0^{\circ} \mathrm{C}$, after which it was freed of solvent in vacuo and the solid was extracted with $\mathrm{C}_{6} \mathrm{D}_{6}$. The solution contained $\mathbf{1} \mathbf{b}$ with only about $2 \%$ of hydrosilylated products 2 and $\mathbf{5}$. This sample was used without further purification to monitor hydrosilylation.

Chloro( ${ }^{\text {(ipp }}$ IMP $\left.(=\mathrm{L})\right)\left({ }^{\text {Dipp }} \mathrm{AMP}\left(=\mathrm{L}^{\prime}\right)\right)$ silane (2): To a solution of $\mathrm{NEt}_{3}$

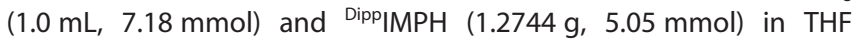
$(50 \mathrm{~mL})$ at $-78^{\circ} \mathrm{C}, \mathrm{HSiCl}_{3}(0.28 \mathrm{~mL}, 2.8 \mathrm{mmol})$ was added. The mixture was stirred at $-78^{\circ} \mathrm{C}$ for $45 \mathrm{~min}$, to give a cloudy, white mixture, which was stirred for $16 \mathrm{~h}$ at RT. The resulting yellow suspension was filtered and the solvent was evaporated in vacuo to give a yellow foam. The solid residue $(1.60 \mathrm{~g})$ was extracted with acetonitrile $(10 \times 7.5 \mathrm{~mL})$, which dissolved $1.01 \mathrm{~g}$. The combined extracts $(75 \mathrm{~mL})$ were stored at $-35^{\circ} \mathrm{C}$ and, after three days, compound 2 $(0.473 \mathrm{~g}, 0.828 \mathrm{mmol}, 33 \%)$ formed as orange needle-shaped crystals, which were suitable for XRD crystallography. ${ }^{1} \mathrm{H} N M R$ $\left(400 \mathrm{MHz}, \quad \mathrm{C}_{6} \mathrm{D}_{6}, \quad 25^{\circ} \mathrm{C}\right): \quad \delta=7.37\left(\mathrm{dd},{ }^{4} \mathrm{~J}(\mathrm{H}, \mathrm{H})=1.2 \mathrm{~Hz},{ }^{5} \mathrm{~J}(\mathrm{H}, \mathrm{H})=\right.$ $0.5 \mathrm{~Hz}, 1 \mathrm{H} ; \quad \mathrm{N}=\mathrm{C}-\mathrm{H}), \quad 7.15-6.85(\mathrm{~m}, 6 \mathrm{H} ; \mathrm{Ar}-\mathrm{H}), 6.39$ (app. dd, ${ }^{3} J(\mathrm{H}, \mathrm{H})=4.0 \mathrm{~Hz},{ }^{4} J(\mathrm{H}, \mathrm{H})=0.9 \mathrm{~Hz}, 1 \mathrm{H}$; L-pyrrole- $\left.H 5\right), 6.31$ (br. s, $1 \mathrm{H}$; L-pyrrole-H3), $6.25(\mathrm{~m}, 1 \mathrm{H}$; L'-pyrrole- $H 5), 6.14\left(\mathrm{t},{ }^{3} \mathrm{~J}(\mathrm{H}, \mathrm{H})=2.8 \mathrm{~Hz}\right.$, $1 \mathrm{H}$; L'-pyrrole-H4), $5.94(\mathrm{~m}, 1 \mathrm{H}$; L'-pyrrole- $H 3), 5.79\left(\mathrm{ddd},{ }^{3} \mathrm{~J}(\mathrm{H}, \mathrm{H})=\right.$ $4.0 \mathrm{~Hz},{ }^{3} \mathrm{~J}(\mathrm{H}, \mathrm{H})=2.0 \mathrm{~Hz},{ }^{5} \mathrm{~J}(\mathrm{H}, \mathrm{H})=0.5 \mathrm{~Hz}, 1 \mathrm{H}$; pyrrole- $\left.\mathrm{H4}\right), 4.49(\mathrm{~d}$, $\left.{ }^{2} J(\mathrm{H}, \mathrm{H})=14.0 \mathrm{~Hz}, 1 \mathrm{H} ; \mathrm{N}-\mathrm{CH}_{2}\right), 4.32\left(\mathrm{~d},{ }^{2} \mathrm{~J}(\mathrm{H}, \mathrm{H})=14.0 \mathrm{~Hz}, 1 \mathrm{H} ; \mathrm{N}-\mathrm{CH}_{2}\right)$, $3.69\left(\right.$ sept, $\left.^{3} \mathrm{~J}(\mathrm{H}, \mathrm{H})=6.8 \mathrm{~Hz}, 1 \mathrm{H} ; i \operatorname{Pr} \mathrm{CH}\right), 3.49\left(\right.$ sept $^{3} \mathrm{~J}(\mathrm{H}, \mathrm{H})=6.8 \mathrm{~Hz}$, $1 \mathrm{H} ; i \operatorname{Pr} \mathrm{CH}), 3.41\left(\mathrm{sept}^{3} \mathrm{~J}(\mathrm{H}, \mathrm{H})=6.8 \mathrm{~Hz}, 1 \mathrm{H} ; i \operatorname{Pr} \mathrm{CH}\right), 3.25$ (sept, $\left.{ }^{3} \mathrm{~J}(\mathrm{H}, \mathrm{H})=6.8 \mathrm{~Hz}, 1 \mathrm{H} ; \mathrm{iPr} \mathrm{CH}\right), 1.46\left(\mathrm{~d},{ }^{3} \mathrm{~J}(\mathrm{H}, \mathrm{H})=6.7 \mathrm{~Hz}, 3 \mathrm{H} ; i \operatorname{Pr}-\mathrm{CH}_{3}\right)$, $1.40\left(\mathrm{~d},{ }^{3} \mathrm{~J}(\mathrm{H}, \mathrm{H})=6.7 \mathrm{~Hz}, 3 \mathrm{H} ; \mathrm{PPr}-\mathrm{CH}_{3}\right), 1.21\left(\mathrm{~d},{ }^{3} \mathrm{~J}(\mathrm{H}, \mathrm{H})=6.8 \mathrm{~Hz}, 3 \mathrm{H}\right.$; $\left.i \operatorname{Pr}-\mathrm{CH}_{3}\right), 1.09\left(\mathrm{~d},{ }^{3} \mathrm{~J}(\mathrm{H}, \mathrm{H})=6.8 \mathrm{~Hz}, 3 \mathrm{H} ; i \operatorname{Pr}-\mathrm{CH}_{3}\right), 1.04\left(\mathrm{~d},{ }^{3} \mathrm{~J}(\mathrm{H}, \mathrm{H})=\right.$ $\left.6.9 \mathrm{~Hz}, 3 \mathrm{H} ; i \operatorname{Pr}-\mathrm{CH}_{3}\right), 1.02\left(\mathrm{~d},{ }^{3} \mathrm{~J}(\mathrm{H}, \mathrm{H})=6.8 \mathrm{~Hz} ; 3 \mathrm{H}, i \mathrm{Pr}-\mathrm{CH}_{3}\right), 0.91(\mathrm{~d}$, $\left.{ }^{3} \mathrm{~J}(\mathrm{H}, \mathrm{H})=6.8 \mathrm{~Hz}, 3 \mathrm{H} ; i \mathrm{Pr}-\mathrm{CH}_{3}\right), 0.64 \mathrm{ppm}\left(\mathrm{d},{ }^{3} \mathrm{~J}(\mathrm{H}, \mathrm{H})=6.9 \mathrm{~Hz} ; 3 \mathrm{H}, i \mathrm{Pr}-\right.$ $\left.\mathrm{CH}_{3}\right) ;{ }^{13} \mathrm{C}\left\{{ }^{1} \mathrm{H}\right\}$ NMR $\left(100 \mathrm{MHz}, \mathrm{C}_{6} \mathrm{D}_{6}, 25^{\circ} \mathrm{C}\right): \delta=158.77,149.59,147.63$, $145.07,144.71,142.05,141.94,140.96,132.75,131.34,124.96$, $124.86,123.67,123.38,122.11,120.30,118.20,111.68,99.08,51.61$, $29.85,28.38,28.28,27.93,27.23,26.20,25.92,25.03,23.75,22.72$,
$21.43 \mathrm{ppm} ;{ }^{29} \mathrm{Si}$ NMR $\left(79 \mathrm{MHz}, \mathrm{C}_{6} \mathrm{D}_{6}, 25^{\circ} \mathrm{C}\right): \delta=-116.2 \mathrm{ppm}$; elemental analysis calcd (\%) for $\mathrm{C}_{34} \mathrm{H}_{43} \mathrm{CIN}_{4} \mathrm{Si}$ : C 71.48, H 7.59, N 9.81; found: C 71.23, H 7.37, N 9.71.

Crystallographic details: $\mathrm{C}_{34} \mathrm{H}_{43} \mathrm{CIN}_{4} \mathrm{Si} ; \mathrm{F}_{\mathrm{w}}=571.26$; red block; $0.39 \mathrm{x}$ $0.23 \times 0.13 \mathrm{~mm}^{3}$; monoclinic; $C 2 / c$ (no. 15); $a=20.2550(7), b=$ 9.9597(3), $c=15.6320(4) \AA, \beta=99.764(2)^{\circ} ; V=3107.82(15) \AA^{3} ; Z=4$; $D_{\mathrm{x}}=1.221 \mathrm{~g} \mathrm{~cm}^{-3} ; \mu=0.19 \mathrm{~mm}^{-1} ; 64810$ reflections were measured at a temperature of $100(2) \mathrm{K}$ up to a resolution of $(\sin \theta / \lambda)_{\max }=$ $0.78 \AA^{-1} ; 6268$ reflections were unique $\left(R_{\text {int }}=0.030\right)$, of which 5603 were observed $[I>2 \sigma(I)]$. Atom $C 5$ was refined with a disorder model corresponding to $\mathrm{C}-\mathrm{H}$ and $\mathrm{CH}_{2}$ in a ratio of $1: 1$. The isopropyl group at $\mathrm{C} 15$ was orientationally disordered. Hydrogen atoms were refined with a riding model. 216 Parameters were refined with 61 restraints (distances, angles and displacement parameters of the disordered groups). R1/wR2 [I> 2 $\sigma(I)]: 0.0410 / 0.1067$. R1/ wR2 [all refl.]: $0.0457 / 0.1094 . S=1.023$. Residual electron density between -0.65 and 0.70 e $\AA^{3}$.

Tris( (ipp IMP)silane (3): To a solution of $\mathrm{NEt}_{3}(1.55 \mathrm{~mL}, 11.1 \mathrm{mmol})$ and Dipp IMPH $(1.944 \mathrm{~g}, 7.70 \mathrm{mmol})$ in THF $(12.5 \mathrm{~mL})$ at $-78^{\circ} \mathrm{C}$, $\mathrm{HSiCl}_{3}(0.25 \mathrm{~mL}, 2.5 \mathrm{mmol})$ was added. This mixture was stirred at $-78^{\circ} \mathrm{C}$ for $45 \mathrm{~min}$, to give a cloudy, pale-yellow mixture, which turned green/gray during stirring for $16 \mathrm{~h}$ at RT. The mixture was filtered and the solvent was evaporated. The bulk of the product was purified by dissolving the solid residue $(1.551 \mathrm{~g})$ in THF $(14 \mathrm{~mL})$, filtration, and storage of the dark-green solution at $-35^{\circ} \mathrm{C}$ in a glovebox. Clear colorless crystals formed after three days (583 mg). To obtain a second crop, the liquid was separated, concentrated to about two-third the volume and stored at $-35^{\circ} \mathrm{C}$ again. After three days, a second crop was isolated $(95.5 \mathrm{mg})$. The crystals were washed with $n$-hexane $(1 \mathrm{~mL})$ and freed of solvent in vacuo. White/slightly green crystals were obtained (total: $678 \mathrm{mg}$, $34 \%)$. Crystals suitable for X-ray diffraction analysis were obtained by vapor diffusion of $n$-hexane $(4 \mathrm{~mL})$ into a solution of the crude product $(0.5 \mathrm{~g})$ in THF $(2 \mathrm{~mL}) .{ }^{1} \mathrm{H}$ NMR $\left(400 \mathrm{MHz}, \mathrm{C}_{6} \mathrm{D}_{6}, 25^{\circ} \mathrm{C}\right): \delta=$ $7.68(\mathrm{~s}, 3 \mathrm{H} ; \mathrm{N}=\mathrm{C}-\mathrm{H}), 7.60\left(\mathrm{~s}, 1 \mathrm{H} ; \mathrm{Si}-\mathrm{H},{ }^{1} J(\mathrm{Si}, \mathrm{H})=417 \mathrm{~Hz}\right), 6.99(\mathrm{~s}, 9 \mathrm{H}$; Ar- $H), 6.44\left(\mathrm{dd},{ }^{3} J(\mathrm{H}, \mathrm{H})=1.24 \mathrm{~Hz},{ }^{3}(\mathrm{H}, \mathrm{H})=3.25 \mathrm{~Hz}, 3 \mathrm{H}\right.$; pyrrole- $\left.H\right)$, $6.08(\mathrm{~m}, 6 \mathrm{H}$; pyrrole- $H), 2.60(\mathrm{br}, 3 \mathrm{H} ; \mathrm{iPr} \mathrm{CH}), 1.83(\mathrm{br}, 3 \mathrm{H} ; \mathrm{iPr} \mathrm{CH})$, $0.98\left(\mathrm{~d},{ }^{3} \mathrm{~J}(\mathrm{H}, \mathrm{H})=6.9 \mathrm{~Hz}, 18 \mathrm{H} ; \quad \mathrm{Pr}-\mathrm{CH}_{3}\right), 0.79\left(\mathrm{br}, 9 \mathrm{H} ; \mathrm{iPr}-\mathrm{CH}_{3}\right)$, $0.59 \mathrm{ppm}\left(\mathrm{br}, 9 \mathrm{H} ; \mathrm{iPr}-\mathrm{CH}_{3}\right) ;{ }^{1} \mathrm{H}$ NMR $\left(400 \mathrm{MHz}, \mathrm{C}_{7} \mathrm{D}_{8},-60^{\circ} \mathrm{C}\right): \delta=$ $7.54\left(\mathrm{~s}, 1 \mathrm{H} ;{ }^{1} J(\mathrm{Si}, \mathrm{H})=417 \mathrm{~Hz} ; \mathrm{Si}-\mathrm{H}\right), 7.43(\mathrm{~s}, 3 \mathrm{H} ; \mathrm{N}=\mathrm{C}-\mathrm{H}), 7.14-6.93$ $(\mathrm{m}, 9 \mathrm{H} ; \operatorname{Ar}-\mathrm{H}), 6.38\left(\mathrm{dd},{ }^{3} \mathrm{~J}(\mathrm{H}, \mathrm{H})=1.5 \mathrm{~Hz},{ }^{3} \mathrm{~J}(\mathrm{H}, \mathrm{H})=3.4 \mathrm{~Hz}, 3 \mathrm{H}\right.$; pyrrole-H), 6.13 (br, $3 \mathrm{H}$; pyrrole- $H$ ), 6.03 (app.t, ${ }^{3} J(\mathrm{H}, \mathrm{H})=3.0 \mathrm{~Hz}, 3 \mathrm{H}$; pyrrole- $H)$, $2.60\left(\right.$ sept, $\left.{ }^{3} J(\mathrm{H}, \mathrm{H})=6.9 \mathrm{~Hz}, 3 \mathrm{H} ; i \operatorname{Pr} \mathrm{CH}\right), 1.64$ (sept, $\left.{ }^{3} \mathrm{~J}(\mathrm{H}, \mathrm{H})=6.9 \mathrm{~Hz}, 3 \mathrm{H} ; i \operatorname{Pr} \mathrm{CH}\right), 1.09\left(\mathrm{~d},{ }^{3} \mathrm{~J}(\mathrm{H}, \mathrm{H})=6.9 \mathrm{~Hz}, 9 \mathrm{H} ; i \operatorname{Pr}-\mathrm{CH}_{3}\right)$, $1.05\left(\mathrm{~d},{ }^{3} J(\mathrm{H}, \mathrm{H})=6.9 \mathrm{~Hz}, 9 \mathrm{H} ; i \operatorname{Pr}-\mathrm{CH}_{3}\right), 0.90\left(\mathrm{~d},{ }^{3} \mathrm{~J}(\mathrm{H}, \mathrm{H})=6.9 \mathrm{~Hz}, 9 \mathrm{H}\right.$; iPr- $\left.\mathrm{CH}_{3}\right), 0.44 \mathrm{ppm}\left(\mathrm{d},{ }^{3} \mathrm{~J}(\mathrm{H}, \mathrm{H})=6.9 \mathrm{~Hz}, 9 \mathrm{H} ; \quad i \mathrm{Pr}-\mathrm{CH}_{3}\right) ;{ }^{13} \mathrm{C}\{\mathrm{H}\} \mathrm{NMR}$ $\left(100 \mathrm{MHz}, \mathrm{C}_{7} \mathrm{D}_{8}, 25^{\circ} \mathrm{C}\right): \delta=152.9,148.6,138.6(\mathrm{br}), 136.5,131.1$, $124.5,123.4,122.4$ (br), 120.9, 113.0, 110.3, 28.3, 27.7, 26.0 (br), 25.0 (br), 23.7, $22.3 \mathrm{ppm}(\mathrm{br}) ;{ }^{13} \mathrm{C}\left\{{ }^{1} \mathrm{H}\right\}$ NMR $\left(100 \mathrm{MHz}, \mathrm{C}_{7} \mathrm{D}_{8},-60^{\circ} \mathrm{C}\right): \delta=$ $152.4(\mathrm{~N}=\mathrm{C}-H), 148.2(i-\mathrm{Ar}), 139.3$ (o-Ar), 137.6 (o-Ar), 135.9 (pyr-C), 130.7 (pyr-CH), 124.3 (Ar-CH), $123.3($ Ar-CH), 121.8 (Ar-CH), 120.7 (pyr-CH), 112.7 (pyr-CH), $27.6(i \operatorname{Pr} C H), 27.2(i \operatorname{Pr} C H), 26.3\left(i \operatorname{Pr}-\mathrm{CH}_{3}\right)$,

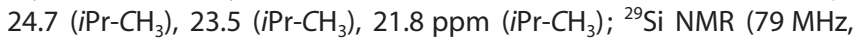
$\left.\mathrm{C}_{6} \mathrm{D}_{6}, \quad 25^{\circ} \mathrm{C}\right) ; \quad \delta=-60.5 \mathrm{ppm} \quad\left({ }^{1} J(\mathrm{Si}, \mathrm{H})=417 \mathrm{~Hz}\right) ; \quad$ IR $\quad$ (ATR): $\quad \tilde{v}=$ $2355 \mathrm{~cm}^{-1}(\mathrm{Si}-\mathrm{H}), 1628 \mathrm{~cm}^{-1}(\mathrm{C}=\mathrm{N})$; elemental analysis calcd (\%) for $\mathrm{C}_{51} \mathrm{H}_{64} \mathrm{~N}_{6} \mathrm{Si}$ : C 77.62, H 8.17, N 10.65; found: C 77.58, H 8.15, N 10.65 .

Crystallographic details: $\mathrm{C}_{51} \mathrm{H}_{64} \mathrm{~N}_{6} \mathrm{Si}$; $\mathrm{Fw}=789.17$; colorless block; $0.48 \times 0.47 \times 0.17 \mathrm{~mm}^{3}$; monoclinic; $P 2_{1} / n$ (no. 14 ); $a=17.5336(6)$, $b=13.3186(6), c=19.7879(6) \AA, \beta=91.542(2)^{\circ} ; V=4619.3(3) \AA^{3} ; Z=$ $4 ; D_{\mathrm{x}}=1.135 \mathrm{~g} \mathrm{~cm}^{-3} ; \mu=0.09 \mathrm{~mm}^{-1} ; 56581$ reflections were measured at a temperature of $150(2) \mathrm{K}$ up to a resolution of $(\sin \theta /$ $\lambda)_{\max }=0.65 \AA^{-1} ; 10604$ reflections were unique $\left(R_{\mathrm{int}}=0.039\right)$, of 
which 8297 were observed $[I>2 \sigma(l)]$. One of the isopropyl groups was refined with a disorder model. The $\mathrm{Si}-\mathrm{H}$ hydrogen atom was refined freely with an isotropic displacement parameter. All other $\mathrm{H}$-atoms were refined with a riding model. 572 Parameters were refined with 203 restraints (distances and angles of the isopropyl

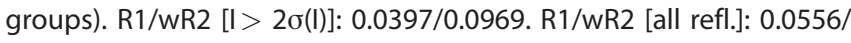
0.1057 . $S=1.025$. Residual electron density between -0.34 and 0.28 e $\AA^{3}$.

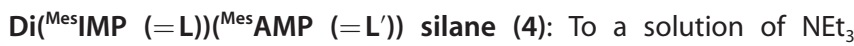
$(1.52 \mathrm{~mL}, 10.9 \mathrm{mmol})$ and ${ }^{\mathrm{Mes}} \mathrm{IMPH}(1.624 \mathrm{~g}, 7.69 \mathrm{mmol})$ in THF $(12.5 \mathrm{~mL})$ at $-78{ }^{\circ} \mathrm{C}, \mathrm{HSiCl}_{3}(0.25 \mathrm{~mL}, 2.5 \mathrm{mmol})$ was added. This was stirred at $-78^{\circ} \mathrm{C}$ for $45 \mathrm{~min}$, yielding a cloudy, off-white mixture, which turned yellow/orange during stirring for $16 \mathrm{~h}$ at RT. The mixture was filtered and the solvent was evaporated to give a voluminous foam. The bulk of the product was purified by extracting the solid residue $(1.467 \mathrm{~g})$ in THF $(11 \mathrm{~mL})$ and storing the resulting orange solution at $-35^{\circ} \mathrm{C}$ in a glovebox. After two days, no solid material had formed. $n$-Hexane $(11 \mathrm{~mL})$ was carefully layered on top of the clear THF solution and this was stored at RT for three days, after which orange crystals had formed. The liquid was separated, the crystals washed with $n$-hexane $(1 \mathrm{~mL})$, and dried in vacuo $(0.361 \mathrm{~g}, 22 \%)$. Crystals suitable for X-ray analysis were obtained by gas-phase diffusion of $n$-hexane into a solution of 4 in a minimal amount of THF. ${ }^{1} \mathrm{H}$ NMR $\left(400 \mathrm{MHz}, \mathrm{C}_{7} \mathrm{D}_{8}, 25^{\circ} \mathrm{C}\right): \delta=7.73$ (br, $1 \mathrm{H}$; pyrrole- $H), 6.90-6.50(\mathrm{~m}, 9 \mathrm{H}$; Ar- $\mathrm{H}$ and $2 \mathrm{~N}=\mathrm{C}-\mathrm{H}$ and 1 pyrrole- $H$ determined by HSQC), $6.20(\mathrm{br}, 1 \mathrm{H}$; pyrrole- $H), 6.08(\mathrm{br}, 1 \mathrm{H}$; pyrrole- $H), 5.93(\mathrm{br}, 1 \mathrm{H}$; pyrrole- $H), 5.91(\mathrm{br}, 1 \mathrm{H}$; pyrrole- $H), 5.78(\mathrm{br}$, $1 \mathrm{H}$; pyrrole- $H), 5.62(\mathrm{br}, 1 \mathrm{H}$; pyrrole- $H), 5.60(\mathrm{br}, 1 \mathrm{H}$; pyrrole- $H)$, $4.10\left(\mathrm{~d},{ }^{2} J(\mathrm{H}, \mathrm{H})=14.3 \mathrm{~Hz}, 1 \mathrm{H} ; \mathrm{N}-\mathrm{CH}_{2}\right), 4.02\left(\mathrm{~d},{ }^{2} \mathrm{~J}(\mathrm{H}, \mathrm{H})=14.3 \mathrm{~Hz}, 1 \mathrm{H}\right.$; $\left.\mathrm{N}-\mathrm{CH}_{2}\right), 2.38\left(\mathrm{~s}, 3 \mathrm{H}\right.$; Mes- $\left.\mathrm{CH}_{3}\right), 2.30-1.70 \mathrm{ppm}\left(\mathrm{m}, 27 \mathrm{H}\right.$; Mes- $\left.\mathrm{CH}_{3}\right)$; ${ }^{1} \mathrm{H} N M R \quad\left(400 \mathrm{MHz}, \quad \mathrm{C}_{7} \mathrm{D}_{8},-25^{\circ} \mathrm{C}\right): \delta=7.78 \quad(\mathrm{dd}, \quad J(\mathrm{H}, \mathrm{H})=3.4 \mathrm{~Hz}$, $J(\mathrm{H}, \mathrm{H})=1.7 \mathrm{~Hz}, 1 \mathrm{H}$; pyrrole- $H), 6.85-6.40(\mathrm{~m}, 9 \mathrm{H} ; \mathrm{Ar}-\mathrm{H}$ and $2 \mathrm{~N}=\mathrm{C}-\mathrm{H}$ and 1 pyrrole- $H), 6.14(\mathrm{t}, J(\mathrm{H}, \mathrm{H})=3.0 \mathrm{~Hz}, 1 \mathrm{H}$; pyrrole- $H), 6.07(\mathrm{~s}, 1 \mathrm{H}$; pyrrole- $H), 6.03(\mathrm{~s}, 1 \mathrm{H}$; pyrrole- $H), 5.96(\mathrm{t}, J(\mathrm{H}, \mathrm{H})=2.7 \mathrm{~Hz}, 1 \mathrm{H}$; pyrrole- $H), 5.86(\mathrm{dd}, J(\mathrm{H}, \mathrm{H})=1.8 \mathrm{~Hz}, J(\mathrm{H}, \mathrm{H})=3.8 \mathrm{~Hz}, 1 \mathrm{H}$; pyrrole- $H)$, $5.68(\mathrm{dd}, J(\mathrm{H}, \mathrm{H})=1.6 \mathrm{~Hz}, J(\mathrm{H}, \mathrm{H})=2.6 \mathrm{~Hz}, 1 \mathrm{H}$; pyrrole- $H)$, $5.59(\mathrm{t}$, $J(\mathrm{H}, \mathrm{H})=3.1 \mathrm{~Hz}, 2 \mathrm{H}$; pyrrole- $H), 4.02\left(\mathrm{~d},{ }^{2} J(\mathrm{H}, \mathrm{H})=14.4 \mathrm{~Hz}, 1 \mathrm{H} ; \mathrm{N}-\right.$ $\left.\mathrm{CH}_{2}\right), 3.89\left(\mathrm{~d},{ }^{2} \mathrm{~J}(\mathrm{H}, \mathrm{H})=14.4 \mathrm{~Hz}, 1 \mathrm{H} ; \mathrm{N}-\mathrm{CH}_{2}\right), 2.33\left(\mathrm{~s}, 1 \mathrm{H}\right.$; Mes- $\left.\mathrm{CH}_{3}\right)$, $2.28\left(\mathrm{~s}, 2 \mathrm{H}\right.$; Mes- $\left.\mathrm{CH}_{3}\right), 2.17\left(\mathrm{~s}, 1 \mathrm{H}\right.$; Mes- $\left.\mathrm{CH}_{3}\right), 2.10\left(\mathrm{~s}, 1 \mathrm{H}\right.$; Mes- $\left.\mathrm{CH}_{3}\right)$, $2.04\left(\mathrm{~s}, 1 \mathrm{H}\right.$; Mes- $\left.\mathrm{CH}_{3}\right), 1.90\left(\mathrm{~s}, 1 \mathrm{H}\right.$; Mes- $\left.\mathrm{CH}_{3}\right), 1.87\left(\mathrm{~s}, 1 \mathrm{H}\right.$; Mes- $\left.\mathrm{CH}_{3}\right)$, $1.71 \mathrm{ppm}\left(\mathrm{s}, 1 \mathrm{H}\right.$; Mes- $\left.\mathrm{CH}_{3}\right) ;{ }^{13} \mathrm{C}\left\{{ }^{1} \mathrm{H}\right\}$ NMR $\left(100 \mathrm{MHz}, \mathrm{C}_{7} \mathrm{D}_{8}, 25^{\circ} \mathrm{C}\right): \delta=$ $160.4,156.0,150.6,142.4,141.89,141.53,141.37,138.27,137.21$, 137.14, 135.09, 134.14 (br), 133.74, 133.29 (br), 132.76, 131.31, $130.77,129.64,129.49,129.43,129.22,128.78,128.30,128.18$, $128.06,127.94,127.82,127.21,121.69,119.98,118.02,115.44$, $113.22,110.83,100.43,48.00,21.05,20.97,20.91,20.89,20.81$, $19.91,19.25$ (br), 19.03, 18.90, 18.79, $18.56 \mathrm{ppm} ;{ }^{29} \mathrm{Si} \mathrm{NMR}(79 \mathrm{MHz}$, $\left.\mathrm{C}_{6} \mathrm{D}_{6}, 25^{\circ} \mathrm{C}\right) ; \delta=-120.4 \mathrm{ppm}$; elemental analysis calcd (\%) for $\mathrm{C}_{42} \mathrm{H}_{46} \mathrm{~N}_{6} \mathrm{Si}$ : C 76.09, H 6.99, N 12.68; found: C 75.93, H 7.05, N 12.62 .

Crystallographic details: $\mathrm{C}_{42} \mathrm{H}_{46} \mathrm{~N}_{6} \mathrm{Si} ; \mathrm{F}_{\mathrm{w}}=662.94$; yellow block; $0.59 \times$ $0.36 \times 0.12 \mathrm{~mm}^{3}$; monoclinic; $P 2_{1} / n$ (no. 14), ; $a=20.5288(8), \quad b=$ 9.0717(3), $c=21.4439(5) \AA, \beta=115.714(1)^{\circ} ; V=3598.05(19) \AA^{3} ; Z=$ $4 ; D_{\mathrm{x}}=1.224 \mathrm{~g} \mathrm{~cm}^{-3} ; \mu=0.10 \mathrm{~mm}^{-1} ; 51677$ reflections were measured at a temperature of $150(2) \mathrm{K}$ up to a resolution of $(\sin \theta /$ $\lambda)_{\max }=0.65 \AA^{-1} ; 8270$ reflections were unique $\left(R_{\text {int }}=0.021\right)$, of which 7272 were observed $[I>2 \sigma(l)]$. The hydrogen atoms at the $\mathrm{C} 5 \mathrm{x} \mathrm{C}-\mathrm{H}$ and $\mathrm{CH}_{2}$ groups were refined freely with isotropic displacement parameters. All other $\mathrm{H}$-atoms were refined with a riding model. 467 Parameters were refined with no restraints. $R 1 /$ $w R 2$ [I>2 $\sigma(l)$ ]: 0.0357/0.0986. R1/wR2 [all refl.]: 0.0410/0.1025. $\mathrm{S}=$ 1.048. Residual electron density between -0.32 and 0.30 e $\AA^{3}$.

\section{Reactivity studies}

Hydrosilylation of isolated $1 \mathrm{~b}$ at $70^{\circ} \mathrm{C}$ : An NMR sample was prepared by dissolving crystalline $\mathbf{1} \mathbf{b}(12.9 \mathrm{mg}, 36.5 \mu \mathrm{mol})$ and mesitylene $(2.9 \mathrm{mg}, 24 \mu \mathrm{mol})$ in $\mathrm{C}_{6} \mathrm{D}_{6}$ (ca. $0.5 \mathrm{~mL}$ ). This mixture was monitored by ${ }^{1} \mathrm{H}$ NMR spectroscopic analysis for $73 \mathrm{~h}$ at RT. Subsequent$l y$, a programmed sequence of ${ }^{1} \mathrm{H}$ NMR measurements was conducted at $70^{\circ} \mathrm{C}$ for $61 \mathrm{~h}$. All spectra were recorded with a relaxation time of $10 \mathrm{~s}$. The ratio of the signal area per $\mathrm{H}$ of the compound and the signal area per $\mathrm{H}$ of the mesitylene internal standard (IS) multiplied by the amount of IS gives the amount of compound. The concentration was obtained by dividing this by the approximated $0.5 \mathrm{~mL}$ solvent. From this it follows that the absolute concentrations have a certain error which is unknown, whereas the relative concentrations are accurate. The accuracy of the measurements by comparing different resonances of the same compound is given in the Supporting Information, Figure S48; Figure 7 shows the average of these sets.

Reaction of $\mathbf{1} \mathbf{b}$ with ${ }^{\text {Dipp }}$ IMPLi to give 6 : Compounds $\mathbf{1}$ b $(8.2 \mathrm{mg}$,

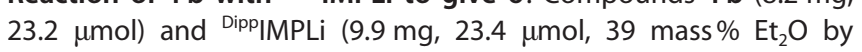
${ }^{1} \mathrm{H}$ NMR spectroscopic analysis) were weighed and dissolved separately, both in $C_{7} D_{8}(0.25 \mathrm{~mL})$. A few drops of $\left[D_{8}\right] T H F$ were needed

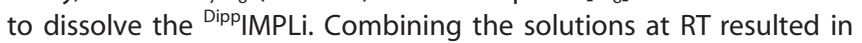
a strongly cloudy solution immediately, which was stirred for $3 \mathrm{~min}$ prior to filtration into a J-Young NMR tube. NMR measurements were done at $-60^{\circ} \mathrm{C}$ and subsequently during warming at steps of $10^{\circ} \mathrm{C}$. ${ }^{1} \mathrm{H}$ NMR spectra showed the presence of 3 in a $6 / 3$ ratio of ca. 3:1. Spectroscopic data for $6:{ }^{1} \mathrm{H}$ NMR $\left(400 \mathrm{MHz}, \mathrm{C}_{7} \mathrm{D}_{8},-60^{\circ} \mathrm{C}\right)$ : $\delta=7.91(\mathrm{~s}, 1 \mathrm{H} ; \mathrm{N}=\mathrm{CH}), 7.75(\mathrm{~s}, 1 \mathrm{H} ; \mathrm{N}=\mathrm{CH}), 7.20(\mathrm{~s}, 1 \mathrm{H} ; \mathrm{Ar}-\mathrm{H}), 6.75$ (app.t, $J(H, H)=6.3 \mathrm{~Hz}, 2 \mathrm{H}$; Ar- $H), 6.60(\mathrm{~s}, 1 \mathrm{H}$; pyrrole- $H), 6.56(\mathrm{t}$, ${ }^{3} J(\mathrm{H}, \mathrm{H})=3.8 \mathrm{~Hz}, 2 \mathrm{H}$; pyrrole- $\left.H\right), 5.93(\mathrm{dd}, J(\mathrm{H}, \mathrm{H})=2.0 \mathrm{~Hz}, J(\mathrm{H}, \mathrm{H})=$ $3.5 \mathrm{~Hz}, 1 \mathrm{H}$; pyrrole- $H), 5.87(\mathrm{dd}, J(\mathrm{H}, \mathrm{H})=2.0 \mathrm{~Hz}, J(\mathrm{H}, \mathrm{H})=3.5 \mathrm{~Hz}, 1 \mathrm{H}$; pyrrole- $H), 5.83\left(\mathrm{~s},{ }^{1} \mathrm{~J}(\mathrm{Si}, \mathrm{H})=285 \mathrm{~Hz}, 1 \mathrm{H}\right.$; Si-H), $3.66\left(\right.$ sept, $^{3} \mathrm{~J}(\mathrm{H}, \mathrm{H})=$ $6.5 \mathrm{~Hz}, 1 \mathrm{H} ; \mathrm{iPr} \mathrm{CH}), 3.01\left(\mathrm{sept},{ }^{3} J(\mathrm{H}, \mathrm{H})=6.5 \mathrm{~Hz}, 1 \mathrm{H} ; \operatorname{PPr} \mathrm{CH}\right), 2.93$ (sept, $\left.{ }^{3} J(\mathrm{H}, \mathrm{H})=6.5 \mathrm{~Hz}, 1 \mathrm{H} ; i \operatorname{Pr} \mathrm{CH}\right), 2.87\left(\right.$ sept $^{3} J(\mathrm{H}, \mathrm{H})=6.5 \mathrm{~Hz}, 1 \mathrm{H}$; $i \operatorname{Pr} \mathrm{CH}), 1.50\left(\mathrm{~d},{ }^{3} J(\mathrm{H}, \mathrm{H})=6.5 \mathrm{~Hz}, 3 \mathrm{H} ; \operatorname{iPr}-\mathrm{CH}_{3}\right), 1.20-0.80$ ppm (m, $21 \mathrm{H}$; $\left.i \mathrm{Pr}-\mathrm{CH}_{3}\right) ;{ }^{1} \mathrm{H}$ NMR $\left(400 \mathrm{MHz}, \mathrm{C}_{7} \mathrm{D}_{8}, 25^{\circ} \mathrm{C}\right): \delta=7.76(\mathrm{br}), 7.21$ (br), 7.01 (br), 6.58 (br), 6.44 (br), 5.98 (br), 2.96 ppm (br, iPr CH); ${ }^{29} \mathrm{Si} \mathrm{NMR} \quad\left(79 \mathrm{MHz}, \quad \mathrm{C}_{7} \mathrm{D}_{81} \quad-60^{\circ} \mathrm{C}\right): \delta=-168.5 \mathrm{ppm} \quad\left({ }^{1} \mathrm{~J}(\mathrm{Si}, \mathrm{H})=\right.$ $285 \mathrm{~Hz})$.

Hydrosilylation of $\mathbf{1 b}$ in the presence of $\mathrm{Bu}_{4} \mathrm{NCl}$ : Two NMR samples (experiment and control) were prepared by dissolving crystals of $1 \mathbf{b}$ (Exp: $10.1 \mathrm{mg}$; Control: $11.5 \mathrm{mg}$ ), mesitylene (Exp: $2.8 \mathrm{mg}$; Control: $2.4 \mathrm{mg}$ ) and $\mathrm{Bu}_{4} \mathrm{NCl}$ (low solubility, Exp: $3 \mathrm{mg}$; Control: $0 \mathrm{mg}$ ) in $\mathrm{C}_{6} \mathrm{D}_{6}$ (ca. $0.5 \mathrm{~mL}$ ). The undissolved $\mathrm{Bu}_{4} \mathrm{NCl}$ was filtered off. The concentration of $\mathrm{Bu}_{4} \mathrm{NCl}$ was determined to be $5-6 \mathrm{~mol} \%$ vs. $1 \mathbf{b}$ (determined by ${ }^{1} \mathrm{H}$ NMR integration versus the mesitylene internal standard). A sequence of ${ }^{1} \mathrm{H}$ NMR measurements was conducted at $25^{\circ} \mathrm{C}$ over $5.5 \mathrm{~h}$ (for Control) and 18 days (for experiment). All spectra were recorded with a relaxation time of $10 \mathrm{~s}$. The ratio of the signal area per $\mathrm{H}$ of the compound and the signal area per $\mathrm{H}$ of the IS multiplied by the amount of IS gives the amount of compound. The concentration was obtained by dividing this by the approximated $0.5 \mathrm{~mL}$ solvent. From this it follows that the absolute concentrations have a certain error which is unknown, whereas the relative concentrations are accurate. The reaction profile is given in the Supporting Information, Figure S49. The final data point shows a purity of ca. $80 \% \mathbf{5}$. Spectroscopic data for $\mathbf{5}$ : ${ }^{1} \mathrm{H}$ NMR $\left(400 \mathrm{MHz}, \mathrm{C}_{6} \mathrm{D}_{6}, 25^{\circ} \mathrm{C}\right): \delta=7.14,7.04\left(\mathrm{AB}_{2}, J_{A B}=7.8 \mathrm{~Hz}, 3 \mathrm{H}\right.$; Ar- $\mathrm{H}), 6.77\left(\mathrm{ddt},{ }^{3} \mathrm{~J}(\mathrm{H}, \mathrm{H})=2.8 \mathrm{~Hz},{ }^{4} J(\mathrm{H}, \mathrm{H})=1.0 \mathrm{~Hz},{ }^{5} \mathrm{~J}(\mathrm{H}, \mathrm{H})=0.6 \mathrm{~Hz}\right.$, $1 \mathrm{H}$; pyrrole- $H 5), 6.46\left(\mathrm{t},{ }^{3} J(\mathrm{H}, \mathrm{H})=3.0 \mathrm{~Hz}, 1 \mathrm{H}\right.$; pyrrole- $\left.\mathrm{H} 4\right), 6.01(\mathrm{dq}$, ${ }^{3} J(\mathrm{H}, \mathrm{H})=3.1 \mathrm{~Hz},{ }^{4} J(\mathrm{H}, \mathrm{H})=1.2 \mathrm{~Hz}, 1 \mathrm{H}$; pyrrole- $\left.\mathrm{H} 3\right), 4.22\left(\mathrm{dd},{ }^{4} J(\mathrm{H}, \mathrm{H})=\right.$ $\left.1.4 \mathrm{~Hz},{ }^{5} J(\mathrm{H}, \mathrm{H})=0.7 \mathrm{~Hz}, 2 \mathrm{H} ; \mathrm{N}-\mathrm{CH}_{2}\right), 3.30\left(\right.$ sept, $^{3} \mathrm{~J}(\mathrm{H}, \mathrm{H})=6.8 \mathrm{~Hz}, 2 \mathrm{H}$;

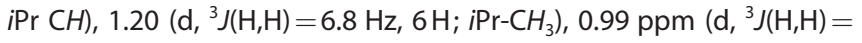


$\left.6.8 \mathrm{~Hz}, 6 \mathrm{H} ; i \mathrm{Pr}-\mathrm{CH}_{3}\right) ;{ }^{29} \mathrm{Si} \mathrm{NMR}\left(79 \mathrm{MHz}, \mathrm{C}_{6} \mathrm{D}_{6}, 25^{\circ} \mathrm{C}, \mathrm{Cr}(\mathrm{acac})_{3}\right) ; \delta=$ $-36.5 \mathrm{ppm}$.

\section{Acknowledgements}

We thank SURFsara (www.surfsara.nl) for support in using the Lisa Compute Cluster. The X-ray diffractometer was financed by the Netherlands Organization for Scientific Research (NWO). Support with NMR spectroscopic analysis by Dr. J.T.B.H. Jastrzebski is gratefully acknowledged. We acknowledge funding from the European Union Seventh Framework Programme (FP7/2007-2013) under grant agreement PIIF-GA-2012-327306 (IIF-Marie Curie grant awarded to M.E.M.), the Dutch National Research School Combination Catalysis (NRSC-C), and the Sectorplan Natuur- en Scheikunde (Tenure-track grant at Utrecht University). We thank Claire C. Patandin and Laura V. de Paus for preliminary synthetic studies on compound 4 .

Keywords: density functional calculations - hydrosilylation hypervalent compounds · ligand effects $\cdot$ silicon

[1] K. Hübler, W. R. Roper, L. J. Wright, Organometallics 1997, 16, 2730 2735.

[2] A. Brück, D. Gallego, W. Wang, E. Irran, M. Driess, J. F. Hartwig, Angew. Chem. Int. Ed. 2012, 51, 11478-11482; Angew. Chem. 2012, 124, $11645-$ 11649.

[3] B. Blom, M. Stoelzel, M. Driess, Chem. Eur. J. 2013, 19, 40-62.

[4] M. Denk, R. Lennon, R. Hayashi, R. West, A. V. Belyakov, H. P. Verne, A. Haaland, M. Wagner, N. Metzler, J. Am. Chem. Soc. 1994, 116, $2691-$ 2692.

[5] A. J. Arduengo, R. L. Harlow, M. Kline, J. Am. Chem. Soc. 1991, 113, 361 363.

[6] S. Khan, S. S. Sen, D. Kratzert, G. Tavčar, H. W. Roesky, D. Stalke, Chem. Eur. J. 2011, 17, 4283-4290.

[7] W. Yang, H. Fu, H. Wang, M. Chen, Y. Ding, H. W. Roesky, A. Jana, Inorg. Chem. 2009, 48, 5058-5060.

[8] B. Blom, M. Pohl, G. Tan, D. Gallego, M. Driess, Organometallics 2014, 33, $5272-5282$.

[9] C.-W. So, H. W. Roesky, J. Magull, R. B. Oswald, Angew. Chem. Int. Ed. 2006, 45, 3948-3950; Angew. Chem. 2006, 118, 4052-4054.

[10] S. S. Sen, H. W. Roesky, D. Stern, J. Henn, D. Stalke, J. Am. Chem. Soc. 2010, 132, 1123-1126.

[11] S. S. Sen, J. Hey, D. Kratzert, H. W. Roesky, D. Stalke, Organometallics 2012, 31, 435-439.

[12] F. M. Mück, D. Kloß, J. A. Baus, C. Burschka, R. Tacke, Chem. Eur. J. 2014, 20,9620-9626.

[13] Y. Xiong, S. Yao, M. Driess, Chem. Eur. J. 2012, 18, 3316-3320.

[14] G. Tan, B. Blom, D. Gallego, E. Irran, M. Driess, Chem. Eur. J. 2014, 20, 9400-9408.

[15] M. Driess, S. Yao, M. Brym, C. van Wüllen, D. Lentz, J. Am. Chem. Soc. 2006, 128, 9628-9629.

[16] M. Asay, C. Jones, M. Driess, Chem. Rev. 2011, 111, 354-396.

[17] F. Armbruster, I. Fernández, F. Breher, Dalton Trans. 2009, 5612-5626.

[18] F. Armbruster, T. Augenstein, P. Oña-Burgos, F. Breher, Chem. Eur. J. 2013, 19, 17899-17906.

[19] S. Styra, S. González-Gallardo, F. Armbruster, P. Oña-Burgos, E. Moos, M. Vonderach, P. Weis, O. Hampe, A. Grün, Y. Schmitt, M. Gerhards, F. Menges, M. Gaffga, G. Niedner-Schatteburg, F. Breher, Chem. Eur. J. 2013, 19, 8436-8446.

[20] B.-Y. Zheng, X.-J. Jiang, T. Lin, M.-R. Ke, J.-D. Huang, Dyes Pigm. 2015, $112,311-316$.

[21] J. Liu, X. Yang, L. Sun, Chem. Commun. 2013, 49, 11785-11787.

[22] B. L. Bray, P. H. Mathies, R. Naef, D. R. Solas, T. T. Tidwell, D. R. Artis, J. M. Muchowski, J. Org. Chem. 1990, 55, 6317-6328.
[23] M. Xiao, X. Lei, B. Han, M. L. O'neill, R. M. Pearlstein, R. Ho, H. Chandra A. Derecskei-Kovacs, Organoaminosilane Precursors and Methods for Making and Using Same, 2013, U.S. Patent 2013129940.

[24] N. Sakamoto, C. Ikeda, M. Yamamura, T. Nabeshima, J. Am. Chem. Soc. 2011, 133, 4726-4729.

[25] D. Gerlach, E. Brendler, T. Heine, J. Wagler, Organometallics 2007, 26, $234-240$.

[26] D. Gerlach, A. W. Ehlers, K. Lammertsma, J. Wagler, Z. Naturforsch. B 2009, 64, $1571-1579$.

[27] A. Kämpfe, E. Brendler, E. Kroke, J. Wagler, Chem. Eur. J. 2014, 20, 9409 9418.

[28] A. Kämpfe, E. Kroke, J. Wagler, Organometallics 2014, 33, 112-120.

[29] A. Kämpfe, E. Brendler, E. Kroke, J. Wagler, Dalton Trans. 2015, 44, $4744-4750$.

[30] a) J. R. Pankhurst, T. Cadenbach, D. Betz, C. Finn, J. B. Love, Dalton Trans. 2015, 44, 2066-2070; b) T. Yasumoto, K. Yamamoto, H. Tsurugi, K. Mashima, Dalton Trans. 2013, 42, 9120-9128; c) Q. Wang, L. Xiang, H. Song, G. Zi, Inorg. Chem. 2008, 47, 4319-4328; d) J. Leppin, C. Förster, K. Heinze, Inorg. Chem. 2014, 53, 12416-12427; e) J.-Y. Liu, P. Tao, Y.-X. Wang, Y.-S. Li, RSC Adv. 2014, 4, 19433-19439; f) E. Labisbal, L. Rodríguez, A. Vizoso, M. Alonso, J. Romero, J.-A. García-Vázquez, A. Sousa-Pedrares, A. Sousa, Z. Anorg. Allg. Chem. 2005, 631, 2107-2114; g) K. Mashima, H. Tsurugi, J. Organomet. Chem. 2005, 690, 4414-4423.

[31] K. P. Bryliakov, E. A. Kravtsov, L. Broomfield, E. P. Talsi, M. Bochmann, Organometallics 2007, 26, 288-293.

[32] H. Kaneko, H. M. Dietrich, C. Schädle, C. Maichle-Mössmer, H. Tsurugi, K. W. Törnroos, K. Mashima, R. Anwander, Organometallics 2013, 32, $1199-1208$.

[33] H. Hao, S. Bhandari, Y. Ding, H. W. Roesky, J. Magull, H.-G. Schmidt, M. Noltemeyer, C. Cui, Eur. J. Inorg. Chem. 2002, 1060-1065.

[34] L.-C. Liang, C.-W. Yang, M. Y. Chiang, C.-H. Hung, P.-Y. Lee, J. Organomet. Chem. 2003, 679, 135-142.

[35] Y. Yang, N. Zhao, H. Zhu, H. W. Roesky, Organometallics 2012, 31, 1958 1964.

[36] S. Tabthong, T. Nanok, P. Kongsaeree, S. Prabpai, P. Hormnirun, Dalton Trans. 2014, 43, 1348-1359.

[37] S. Pracha, S. Praban, A. Niewpung, G. Kotpisan, P. Kongsaeree, S. Saithong, T. Khamnaen, P. Phiriyawirut, S. Charoenchaidet, K. Phomphrai, Dalton Trans. 2013, 42, $15191-15198$.

[38] S. Qiao, W.-A. Ma, Z.-X. Wang, J. Organomet. Chem. 2011, 696, 2746 2753.

[39] Y. Wei, S. Wang, S. Zhou, Z. Feng, L. Guo, X. Zhu, X. Mu, F. Yao, Organometallics 2015, 34, $1882-1889$.

[40] a) C. E. Anderson, A. S. Batsanov, P. W. Dyer, J. Fawcett, J. A. K. Howard, Dalton Trans. 2006, 5362-5378; b) I. Vránová, R. Jambor, A. Růžička, A. Hoffmann, S. Herres-Pawlis, L. Dostál, Dalton Trans. 2015, 44, 395-400.

[41] K. Lippe, D. Gerlach, E. Kroke, J. Wagler, Organometallics 2009, 28, 621 629.

[42] M. Novák, L. Dostál, M. Alonso, F. De Proft, A. Růžička, A. Lyčka, R. Jambor, Chem. Eur. J. 2014, 20, 2542-2550.

[43] E. Kertsnus-Banchik, I. Kalikhman, B. Gostevskii, Z. Deutsch, M. Botoshansky, D. Kost, Organometallics 2008, 27, 5285-5294.

[44] G. W. Fester, J. Eckstein, D. Gerlach, J. Wagler, E. Brendler, E. Kroke, Inorg. Chem. 2010, 49, 2667-2673.

[45] Y.-S. Li, Y.-R. Li, X.-F. Li, J. Organomet. Chem. 2003, 667, 185-191.

[46] The free enthalpy of activation at a given temperature was calculated by using the equation: $\Delta G^{\neq}=a T\left[9.972+\log \left(T_{c} / \Delta v\right)\right]$, where $a=4.575 \times$ $10^{-3}$ for $\mathrm{kcal} \mathrm{mol}^{-1}$.

[47] A. W. Addison, T. N. Rao, J. Reedijk, J. van Rijn, G. C. Verschoor, J. Chem. Soc. Dalton Trans. 1984, 1349-1356.

[48] IUPAC. Compendium of Chemical Terminology, 2nd ed. (the "Gold Book"). Compiled by A. D. McNaught and A. Wilkinson. Blackwell Scientific Publications, Oxford (1997). XML on-line corrected version: http:// goldbook.iupac.org (2006-) created by M. Nic, J. Jirat, B. Kosata; updates compiled by A. Jenkins. ISBN 0-9678550-9-8. doi:10.1351/goldbook.

[49] E. P. A. Couzijn, J. C. Slootweg, A. W. Ehlers, K. Lammertsma, J. Am. Chem. Soc. 2010, 132, 18127-18140.

[50] A. H. J. F. De Keijzer, F. J. J. De Kanter, M. Schakel, V. P. Osinga, G. W. Klumpp, J. Organomet. Chem. 1997, 548, 29-32.

[51] A. Lends, E. Olszewska, S. Belyakov, N. Erchak, E. Liepinsh, Heteroat. Chem. 2015, 26, 12-28. 
[52] E. P. A. Couzijn, M. Schakel, F. J. J. de Kanter, A. W. Ehlers, M. Lutz, A. L. Spek, K. Lammertsma, Angew. Chem. Int. Ed. 2004, 43, 3440-3442; Angew. Chem. 2004, 116, 3522-3524.

[53] C. Chuit, R. J. P. Corriu, C. Reye, J. C. Young, Chem. Rev. 1993, 93, 1371 1448.

[54] G. van Koten, J. T. B. H. Jastrzebski, J. G. Noltes, J. Organomet. Chem. $1979,177,283-292$.

[55] G. van Koten, J. T. B. H. Jastrzebski, J. G. Noltes, W. M. G. F. Pontenagel, J. Kroon, A. L. Spek, J. Am. Chem. Soc. 1978, 100, 5021-5028.

[56] E. L. Muetterties, J. Am. Chem. Soc. 1969, 91, 4115-4122.

[57] E. L. Muetterties, J. Am. Chem. Soc. 1969, 91, 1636-1643.

[58] H. V. R. Dias, Z. Wang, W. Jin, Coord. Chem. Rev. 1998, 176, 67-86.

[59] K. Junold, J. A. Baus, C. Burschka, R. Tacke, Angew. Chem. Int. Ed. 2012, 51, 7020-7023; Angew. Chem. 2012, 124, 7126-7129.

[60] T. Kaukorat, P. G. Jones, R. Schmutzler, Chem. Ber. 1991, 124, $1335-$ 1346.

[61] E. D. Glendening, K. B. J, A. E. Reed, J. E. Carpenter, J. A. Bohmann, C. M. Morales, C. R. Landis, F. Weinhold, NBO 6.0, 2013

[62] F. H. Allen, O. Kennard, D. G. Watson, L. Brammer, A. G. Orpen, R. Taylor, J. Chem. Soc. Perkin Trans. 2 1987, S1-S19.

[63] J. Woning, J. G. Verkade, Organometallics 1991, 10, 2259-2266.

[64] M. Yamamura, N. Kano, T. Kawashima, Tetrahedron Lett. 2007, 48, 4033 4036.

[65] A. S. Pilcher, P. DeShong, J. Org. Chem. 1996, 61, 6901-6905.

[66] G. G. Furin, O. A. Vyazankina, B. A. Gostevsky, N. S. Vyazankin, Tetrahedron 1988, 44, 2675-2749.

[67] F. Bitto, K. Kraushaar, U. Böhme, E. Brendler, J. Wagler, E. Kroke, Eur. J. Inorg. Chem. 2013, 2954-2962.

[68] G. W. Fester, J. Wagler, E. Brendler, E. Kroke, Eur. J. Inorg. Chem. 2008 $5020-5023$.

[69] G. W. Fester, J. Wagler, E. Brendler, U. Böhme, G. Roewer, E. Kroke, Chem. Eur. J. 2008, 14, 3164-3176.

[70] F. Bitto, J. Wagler, E. Kroke, Eur. J. Inorg. Chem. 2012, 2402-2408.

[71] G. W. Fester, J. Wagler, E. Brendler, U. Böhme, D. Gerlach, E. Kroke, J. Am. Chem. Soc. 2009, 131, 6855-6864.

[72] K. Hensen, R. Mayr-Stein, T. Stumpf, P. Pickel, M. Bolte, H. Fleischer, J. Chem. Soc. Dalton Trans. 2000, 473-477.

[73] K. Junold, K. Sinner, J. A. Baus, C. Burschka, C. Fonseca Guerra, F. M. Bickelhaupt, R. Tacke, Chem. Eur. J. 2014, 20, 16462-16466.
[74] K. Junold, M. Nutz, J. A. Baus, C. Burschka, C. Fonseca Guerra, F. M. Bickelhaupt, R. Tacke, Chem. Eur. J. 2014, 20, 9319-9329.

[75] K. Junold, J. A. Baus, C. Burschka, M. Finze, R. Tacke, Eur. J. Inorg. Chem. 2014, 5099-5102.

[76] F. M. Mück, K. Junold, J. A. Baus, C. Burschka, R. Tacke, Eur. J. Inorg Chem. 2013, $5821-5825$.

[77] G. R. Fulmer, A. J. M. Miller, N. H. Sherden, H. E. Gottlieb, A. Nudelman B. M. Stoltz, J. E. Bercaw, K. I. Goldberg, Organometallics 2010, 29, 2176 2179.

[78] D. M. Dawson, D. A. Walker, M. Thornton-Pett, M. Bochmann, J. Chem Soc. Dalton Trans. 2000, 459-466.

[79] C. Liu, S. Zhou, S. Wang, L. Zhang, G. Yang, Dalton Trans. 2010, 39, 8994-8999.

[80] Gaussian 09, Revision D.01, M. J. Frisch, G. W. Trucks, H. B. Schlegel, G. E. Scuseria, M. A. Robb, J. R. Cheeseman, G. Scalmani, V. Barone, B. Mennucci, G. A. Petersson, H. Nakatsuji, M. Caricato, X. Li, H. P. Hratchian, A. F. Izmaylov, J. Bloino, G. Zheng, J. L. Sonnenberg, M. Hada, M. Ehara, K. Toyota, R. Fukuda, J. Hasegawa, M. Ishida, T. Nakajima, Y. Honda, O. Kitao, H. Nakai, T. Vreven, J. A. Montgomery, Jr., J. E. Peralta, F. Ogliaro, M. Bearpark, J. J. Heyd, E. Brothers, K. N. Kudin, V. N. Staroverov, T. Keith, R. Kobayashi, J. Normand, K. Raghavachari, A. Rendell, J. C. Burant, S. S. lyengar, J. Tomasi, M. Cossi, N. Rega, J. M. Millam, M. Klene, J. E. Knox, J. B. Cross, V. Bakken, C. Adamo, J. Jaramillo, R. Gomperts, R. E. Stratmann, O. Yazyev, A. J. Austin, R. Cammi, C. Pomelli, J. W. Ochterski, R. L. Martin, K. Morokuma, V. G. Zakrzewski, G. A. Voth, P. Salvador, J. J. Dannenberg, S. Dapprich, A. D. Daniels, O. Farkas, J. B. Foresman, J. V. Ortiz, J. Cioslowski, D. J. Fox, Gaussian, Inc., Wallingford CT, 2013.

[81] A. M. M. Schreurs, X. Xian, L. M. J. Kroon-Batenburg, J. Appl. Crystallogr. 2010, 43, 70-82.

[82] G. M. Sheldrick 2008, SADABS. Universität Göttingen, Germany.

[83] G. M. Sheldrick, Acta Crystallogr. Sect. A 2015, 71, 1-8.

[84] G. M. Sheldrick, Acta Crystallogr. Sect. C 2015, 71, 3-8.

[85] A. L. Spek, Acta Crystallogr. Sect. D 2009, 65, 148-155.

Received: December 14, 2015

Published online on March 9, 2016 